\title{
Review \\ Are mHealth a useful tool for self-assessment and rehabilitation of people with multiple sclerosis? A review
}

\author{
Bruno Bonnechère $^{1 *}$, Aki Rintala ${ }^{2}$, Annemie Spooren ${ }^{1}$, Ilse Lamers ${ }^{1,3}$ and Peter Feys ${ }^{1,3}$ \\ 1 REVAL - Rehabilitation Research Center, Faculty of Rehabilitation Sciences, Hasselt University, \\ Diepenbeek, Belgium; bruno.bonnechere@uhasselt.be, annemie.spooren@uhasselt.be, \\ ilse.lamers@uhasselt.be, peter.feys@uhasselt.be \\ 2 Faculty of Social Services and Health Care, LAB University of Applied Sciences, Lahti, Finland; \\ aki.rintala@lab.fi \\ 3 UMSC Hasselt-Pelt, Belgium \\ * Correspondence: bruno.bonnechere@uhasselt.be
}

\begin{abstract}
The development of mobile technology and internet mobile offers new possibilities in both rehabilitation and for patients' assessment in a longitudinal and MS management perspective. However, because the mobile health applications (mHealth) have only been developed recently, the level of evidence supporting the use of mHealth in patients with multiple sclerosis (pwMS) is currently unclear. Therefore, this study aims to list and describe the different mHealth available for rehabilitation and self-assessment of pwMS and to define the level of evidence supporting these interventions for functioning problems categorized within the International Classification of Functioning, Disability and Health (ICF). 36 studies, performed with 22 different mHealth, were included in this review, 30 about rehabilitation and 6 for self-assessment, representing 3,091 patients. For rehabilitation, most of the studies were focusing on cognitive function and fatigue. Concerning the efficacy we found a small but significant effect of the use of mHealth for cognitive training $(\mathrm{SMD}=0.28[0.12 ; 0.45])$ and moderate effect for fatigue $(\mathrm{SMD}=0.61[0.47 ; 0.76])$. mHealth is a promising tool in pwMS but more studies are needed to validate these solutions in the others ICF categories. More replications studies are also needed as most of the mHealth have only been assessed in one single study.
\end{abstract}

Keywords: mHealth; multiple sclerosis; telemonitoring; longitudinal assessment; rehabilitation; fatigue; walking; cognition

\section{Introduction}

Patients with Multiple Sclerosis (pwMS) may manifest heterogeneous symptoms and functioning problems that require continuous and long-term rehabilitation programs in clinical and community settings across the disability spectrum. In high-income countries, the pressure on health care systems is increasing [1] and the continuity of high-level care is threatened due to lack of reimbursement, while in some countries access to the specialized MS centers has always been poor [2]. Furthermore, a vast majority of pwMS often present fatigue, emotional or cognitive dysfunction, or restricted physical mobility or a combination of those which limits access to rehabilitation centers. In this context, the WHO stated that lack of access to specialized centers or healthcare professionals is one of the most important limitations for the rehabilitation process [3]. The use of mobile technologies and electronic health (eHealth) could be an alternative to tackle the abovementioned limitations (i.e., reimbursement issue and lack of access to centers) of rehabilitation of pwMS, or complement current rehabilitation services eHealth is also expected to facilitate the monitoring of functioning of pwMS in-between medical consultations, which is informative to define whether to continue or adapt medical treatment.

The number of healthcare interventions delivered via personal mobile devices (mHealth) has increased exponentially thanks to the availability of mobile technology (the number of smartphone subscriptions worldwide today surpasses six billion and is forecast to further grow by several hundred million in the next few years [4]. The 
development and implementation of mHealth opens new perspectives and opportunities in the healthcare sector. Previous studies highlighted that mHealth has already been accepted by patients. Amongst the most important benefits identified by the patients are: easy access to personalized information, convenience, better information on their health, and the ability to communicate more easily with health care professionals [5,6]. So far most studies have focused on patients with cancer [7-9], patients with cardiovascular diseases [10,11], or older adults with [12] or without cognitive impairment [13].

Concerning pwMS a meta-analysis showed that technology-based distance physical rehabilitation intervention has a positive effect on physical activity and walking ability when compared to usual care or no intervention [14]. Another review synthesized the different eHealth technologies that are available for the management of pwMS [15]. eHealth is a broader term than mHealth; eHealth is composed of the electronic records, self-remote disease monitoring (i.e., blood markers, vital signs), mobile and wired communication for advice and education, and tools to facilitate self-management (i.e., physical activity tracker, rehabilitation exercises reminder or calendar). This previous review was published in 2018 and given the important development of technologysupported rehabilitation tools a lot of new solutions have been developed. Furthermore, there is currently a lack of information about the technology, and the related level of evidence supporting this use, that can be used using mobile technology in pwMS.

Therefore, the aim of this paper is first to describe the different mHealth applications currently available to assist the rehabilitation of pwMS and the tools that exist to perform longitudinal self-assessment of the patients. The second aim is to determine the level of evidence supporting the use of mHealth in pwMS on their functioning according to the International Classification of Functioning, Disability, and Health (ICF).

\section{Methods}

\subsection{Search strategy and selection criteria}

Records were searched on three databases (Pubmed, Biber, and Scopus) to identify eligible studies published between 2011 and June 2021. MeSH terms and free words referring to e-health intervention in pwMS ('multiple sclerosis', 'ms', 'ehealth', 'mhealth', 'mobile apps, smartphone intervention', 'apps', 'self-monitoring, 'self-assessment', 'functioning', 'intervention', 'rehabilitation') were used as keywords. The complete search strategy is presented in Table S1.

\subsection{Eligibility criteria}

A PICOs approach was used as inclusion and exclusion criteria, which were assessed by the study team [16]. 
- Population: pwMS performing training (rehabilitation exercises) or self-assessment in home-environment, studies with inpatient treatment or assisted-rehabilitation were not included.

- Intervention: mHealth rehabilitation intervention (planned and supervised interventions), or self-assessment studies with repeated measurements over time, using any type of support (e.g., smartphones, phones, apps, web applications). Studies using non-specific games, virtual reality or active video games (e.g., Nintendo Wii, Microsoft Xbox Kinect), or computer-supported therapy were not included.

- Control: Usual care or no intervention

- Outcome measures: any type of outcome measure related to the International Classification of Functioning, Disability and Health (ICF).

- Study design: RCTs, explorative studies

A flow diagram of the study selection with the screened articles and the selection process is presented in Figure 1.

\subsection{Quality assessment}

Since we included different types of articles, the critical appraisal of the methodological quality was based on the Downs and Black checklist [17], as this checklist is the best option to assess the quality and risk of bias for both RCT and non-RCT [18].

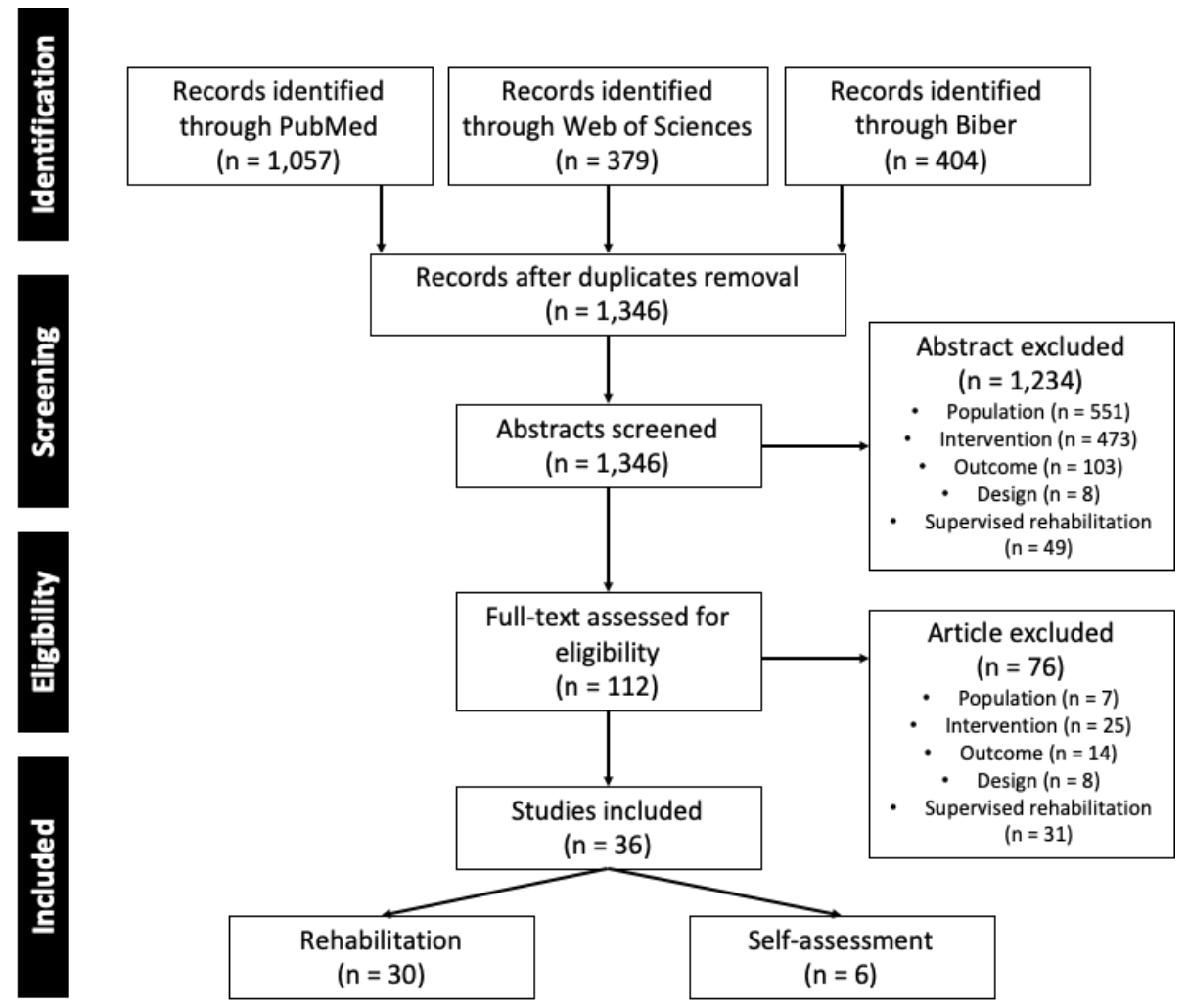

Figure 1. Flowchart of study selection.

\subsection{Data extraction}

The following information was extracted from the included studies: characteristics of the patients (age, sex ratio, type of MS and severity), type and duration of the mHealth intervention, study design, main outcomes, and ICF domains evaluated. 


\subsection{Statistical analysis}

For studies assessing the efficacy of a rehabilitation program, we performed a metaanalysis. The measure of treatment effect was the effect size (standardized mean difference (SMD)), defined as the between-group difference in mean values divided by the pooled SD. If different tests were used to assess the same ICF function in the same study, the different results were pooled to have one unique SMD as recommended by Cochrane's group [19]. A positive SMD implies better therapeutic effects in the intervention group compared to the control. We assessed the heterogeneity in stratified analyse by type of ICF function. We calculated the variance estimate tau ${ }^{2}$ as a measure of between-trial heterogeneity. We prespecified a tau ${ }^{2}$ of 0.0 to represent no heterogeneity, $0.0-0.2$ to represent low heterogeneity, $0.2-0.4$ to represent moderate heterogeneity, and above 0.4 to represent high heterogeneity between trials [20]. We checked for publication bias using funnel plot [21] and Egger's test for the intercept was applied to check the asymmetry [22].

\subsection{Ethical approval}

This systematic review was reported following the Preferred Reporting Items for Systematic Reviews and Meta-Analyses (PRISMA) recommendations [23]. For the present study, no ethics committee approval was necessary.

\section{Results}

For the sake of clarity, this section has been divided into three different parts; first, we will present the characteristics of the included studies and the patients; then we will describe the different mHealth used in these studies and finally, we will present the clinical efficacy for the different domains in the ICF.

\subsection{Search results}

1,346 articles were found with the systematic review. 112 full-text were assessed and 36 papers were included in the analysis. The PRISMA flowchart on the study selection is presented in Figure 1.

\subsection{Characteristics of the included studies}

Thirty studies about the use of mHealth for rehabilitation interventions of pwMS have been included in this review, representing a total of 1,962 patients [24-53]. The majority of these studies $(n=25 ; 3 \%)$ are RCTs. Concerning the patients, the majority of the patients are female $(76 \pm 10 \%)$; concerning the type of MS the majority of the included patients (79\%) have Relapsing-Remitting Multiple Sclerosis (RRMS), 16\% have Secondary Progressive Multiple Sclerosis (SPMS) and 5\% Primary Progressive Multiple Sclerosis (PPMS), and the average EDSS is $3.5 \pm 1.1$. Finally, for the ICF, sixteen (53\%) of the studies reported outcomes related to cognition, $11(37 \%)$ to fatigue, $10(33 \%)$ to quality of life, 7 $(23 \%)$ on motor function, and $6(20 \%)$ on activity level; we observed that most of the studies are assessing different primary outcomes (ICF domains) The complete description of the included studies is presented in Table 1. Amongst the 30 studies, 16 different mHealth apps have been tested.

Concerning the self-assessment tools six studies, using 6 different mHealth applications, have been included in the review, representing 1,129 participants (955 pwMS [88\% with RRMS, 5\% with SPMS and 7\% with PPMS, average EDSS $2.5 \pm 0.5$ ] and 174 healthy participants) [54-59]. The characteristics of the studies and participants are summarized in Table 2. 
Table 1. Characteristics of the included studies on mHealth for rehabilitation

\begin{tabular}{|c|c|c|c|c|c|c|c|c|c|c|c|}
\hline \multirow[t]{2}{*}{ Study } & \multirow{2}{*}{$\begin{array}{l}\text { D\&B } \\
(/ 28)\end{array}$} & \multirow{2}{*}{$\begin{array}{l}\text { Study } \\
\text { design }\end{array}$} & \multirow[t]{2}{*}{ Intervention } & \multirow[t]{2}{*}{ Duration } & \multirow[t]{2}{*}{ Participants } & \multirow{2}{*}{$\begin{array}{c}\text { Type of MS and disability } \\
\text { level }\end{array}$} & \multicolumn{5}{|c|}{ ICF } \\
\hline & & & & & & & 㝘 & 总 & 己ี & 总 & 竞: \\
\hline $\begin{array}{l}\text { Cerasa et al. } \\
2013[24]\end{array}$ & 23 & $\mathrm{RCT}$ & RehaCom & $\begin{array}{l}6 \text { weeks of training } \\
(2 * 60 \mathrm{~min} / \text { week })\end{array}$ & $\begin{array}{c}17 \text { MS patients } \\
33 \text { (4) years old } \\
85 \% \text { female }\end{array}$ & $\begin{array}{c}\text { RRMS: } 17 \\
\text { EDSS: } 3[1,0 ; 4,0]\end{array}$ & & & $\mathrm{X}$ & $\mathrm{X}$ & \\
\hline $\begin{array}{l}\text { Amato et al. } \\
2014[25]\end{array}$ & 21 & $\mathrm{RCT}$ & $\begin{array}{c}\text { Attention Processing Training } \\
\text { Program (APT) }\end{array}$ & $\begin{array}{l}12 \text { weeks of training } \\
(2 * 60 \mathrm{~min} / \text { week })\end{array}$ & $\begin{array}{l}88 \text { MS patients } \\
41 \text { (11) years old } \\
78 \% \text { female }\end{array}$ & $\begin{array}{l}\text { Type not available } \\
\text { EDSS: } 2,7(1,5)\end{array}$ & & & $\mathrm{X}$ & & \\
\hline $\begin{array}{l}\text { Charvet et al. } \\
2015 \text { [26] }\end{array}$ & 24 & $\mathrm{RCT}$ & Luminosity & $\begin{array}{l}12 \text { weeks of training } \\
(5 * 30 \mathrm{~min} / \text { week })\end{array}$ & $\begin{array}{l}20 \text { MS patients } \\
40(8) \text { years old } \\
70 \% \text { female }\end{array}$ & $\begin{array}{c}\text { RRMS: } 20 \\
\text { EDSS: } 2[0 ; 3,5]\end{array}$ & & & $\mathrm{X}$ & & \\
\hline $\begin{array}{l}\text { Hancock et } \\
\text { al. } 2015 \text { [27] }\end{array}$ & 22 & $\mathrm{RCT}$ & $\begin{array}{c}\text { Posit Science inSight (now } \\
\text { BrainHQ) }\end{array}$ & $\begin{array}{l}6 \text { weeks of training } \\
(6 * 30 \mathrm{~min} / \text { week })\end{array}$ & $\begin{array}{l}40 \text { MS patients } \\
50(6) \text { years old }\end{array}$ & Type and EDSS not available & & & $\mathrm{X}$ & & \\
\hline $\begin{array}{l}\text { Fischer et al. } \\
2015 \text { [29] }\end{array}$ & 23 & RCT & Deprexis & 9 weks of training & $\begin{array}{l}90 \text { MS patients } \\
45 \text { (12) years old } \\
78 \% \text { female }\end{array}$ & $\begin{array}{c}\text { RRMS: 40, SPMS: } 21 \text {, PPMS: } \\
\text { 14, unclear: } 18\end{array}$ & & & & & $\mathrm{X}$ \\
\hline $\begin{array}{l}\text { Campbell et } \\
\text { al. } 2016[30]\end{array}$ & 22 & $\mathrm{RCT}$ & RehaCom & $\begin{array}{l}6 \text { weeks of training } \\
(3 * 45 \mathrm{~min} / \text { week })\end{array}$ & $\begin{array}{l}35 \text { MS patients } \\
47 \text { (8) years old } \\
71 \% \text { female }\end{array}$ & $\begin{array}{l}\text { RRMS: } 27, \text { SPMS: } 11 \\
\text { EDSS: } 5,0[3,5 ; 6,0]\end{array}$ & & & $\mathrm{X}$ & & \\
\hline $\begin{array}{l}\text { Pedullà et al. } \\
2016 \text { [31] }\end{array}$ & 24 & $\mathrm{RCT}$ & COGNI-TRAcK & $\begin{array}{l}8 \text { weeks of training } \\
(5 * 30 \mathrm{~min} / \text { week })\end{array}$ & $\begin{array}{l}28 \text { MS patient } \\
47(6) \text { years old } \\
71 \% \text { female }\end{array}$ & $\begin{array}{l}\text { RRMS: 17, SPMS: } 11 \\
\text { EDSS: } 3,8(1,9)\end{array}$ & & & $\mathrm{X}$ & & \\
\hline $\begin{array}{l}\text { Charvet et al. } \\
2017 \text { [32] }\end{array}$ & 23 & $\mathrm{RCT}$ & BrainHQ & $\begin{array}{l}12 \text { weeks of training } \\
(5 * 60 \mathrm{~min} / \text { week })\end{array}$ & $\begin{array}{l}135 \text { MS patients } \\
51 \text { (13) years old } \\
77 \% \text { female }\end{array}$ & $\begin{array}{c}\text { RRMS: } 89 \text {, SPMS: 35, PPMS: } \\
7, \\
\text { EDSS: } 3,5[2,5 ; 4,5]]\end{array}$ & & & $\mathrm{X}$ & & \\
\hline $\begin{array}{l}\text { Messinis et } \\
\text { al. } 2017 \text { [33] }\end{array}$ & 23 & $\mathrm{RCT}$ & RehaCom & $\begin{array}{c}10 \text { weeks of training } \\
(2 * 60 \mathrm{~min} / \text { week })\end{array}$ & $\begin{array}{l}58 \text { MS patients } \\
46(10) \text { years old }\end{array}$ & $\begin{array}{c}\text { RRMS: } 58 \\
\text { EDSS: } 3,2[1,0 ; 5,5]\end{array}$ & & & $\mathrm{X}$ & $\mathrm{X}$ & \\
\hline
\end{tabular}




\begin{tabular}{|c|c|c|c|c|c|c|c|c|c|c|c|}
\hline & & & & & $69 \%$ female & & & & & & \\
\hline $\begin{array}{l}\text { Conroy et al. } \\
2018[34]\end{array}$ & 23 & $\mathrm{RCT}$ & MS HAT system & $\begin{array}{l}6 \text { months of intervention } \\
\text { Self-paced rehabilitation }\end{array}$ & $\begin{array}{l}54 \text { MS patients } \\
50 \text { (12) years old } \\
77 \% \text { female }\end{array}$ & $\begin{array}{c}\text { RRMS: } 14 \text {, SPMS: 35, PPMS: } 2 \\
\text { PDSS: } 4,1(1,5)\end{array}$ & $\mathrm{X}$ & $\mathrm{X}$ & & & \\
\hline $\begin{array}{l}\text { Stuifbergen et } \\
\text { al. } 2018 \text { [35] }\end{array}$ & 22 & $\mathrm{RCT}$ & MAPSS-MS & $\begin{array}{c}8 \text { weeks of training } \\
2 \mathrm{~h} / \text { week group session }+ \\
3 * 45 \mathrm{~min} / \text { week home-based } \\
\text { training program }\end{array}$ & $\begin{array}{c}183 \text { MS patients } \\
50 \text { (8) years old } \\
87 \% \text { female }\end{array}$ & $\begin{array}{l}\text { RRMS: } 124 \\
\text { EDSS } 5.2(1,6)\end{array}$ & & & $\mathrm{X}$ & & $\mathrm{X}$ \\
\hline $\begin{array}{l}\text { Fjeldstad- } \\
\text { Pardo et al. } \\
2018 \text { [36] }\end{array}$ & 21 & $\mathrm{RCT}$ & $\begin{array}{c}\text { CG: exercise sheet } \\
\text { tIG: telerehabilitation } \\
\text { aIG: in-person } \\
\text { rehabilitation + exercise } \\
\text { sheet }\end{array}$ & $\begin{array}{c}8 \text { weeks } \\
\text {-CG: } 5 \mathrm{x} \text { week } \\
\text {-tIG: } 2 \mathrm{x} \text { week } \\
\text {-aIG: } 2 \mathrm{x} \text { week }\end{array}$ & $\begin{array}{c}30 \text { MS patients } \\
55 \text { (12) years old } \\
68 \% \text { female }\end{array}$ & $\begin{array}{c}\text { RRMS: } 18, \text { SPMS: } 8 \text {, PPMS: } 4 \\
\text { EDSS: } 4,3(1,1)\end{array}$ & $\mathrm{X}$ & $\mathrm{X}$ & $X$ & $X$ & $\mathrm{X}$ \\
\hline $\begin{array}{l}\text { Pöttgen et al. } \\
2018 \text { [37] }\end{array}$ & 23 & $\mathrm{RCT}$ & ELEVIDA & $\begin{array}{l}12 \text { weeks of intervention } \\
\text { Self-paced rehabilitation }\end{array}$ & $\begin{array}{c}275 \text { MS patients } \\
41 \text { (11) years old } \\
81 \% \text { female }\end{array}$ & $\begin{array}{c}\text { RRMS: 200, SPMS: 40, PPMS: } \\
\text { 11, unclear: } 24\end{array}$ & & & & $\mathrm{X}$ & $\mathrm{X}$ \\
\hline $\begin{array}{l}\text { Cavalera et } \\
\text { al. } 2019[38]\end{array}$ & 24 & $\mathrm{RCT}$ & $\begin{array}{l}\text { MBSR program } \\
\text { (mindfulness)- MBI } \\
\text { (intervention group) or } \\
\text { online psychoeducation } \\
\text { (active control group) }\end{array}$ & $\begin{array}{l}8 \text { weeks of training } \\
1 \text { weekly session }\end{array}$ & $\begin{array}{l}121 \text { MS patients } \\
42 \text { (8) years old } \\
34 \% \text { female }\end{array}$ & $\begin{array}{l}\text { RRMS: 113; SPMS: } 8 \\
\text { EDSS: median } 3\end{array}$ & & & & & $\mathrm{X}$ \\
\hline $\begin{array}{l}\text { Chiaravalloti } \\
\text { et al. 2018 } \\
\text { [39] }\end{array}$ & 23 & $\mathrm{RCT}$ & $\begin{array}{l}\text { Processing speed apps } \\
\text { (similar to BrainHQ) }\end{array}$ & $\begin{array}{l}5 \text { weeks of training } \\
\text { 2/week }\end{array}$ & $\begin{array}{l}21 \text { MS patients } \\
48 \text { (8) years old } \\
75 \% \text { female }\end{array}$ & RRMS: 21 & & & $\mathrm{X}$ & & \\
\hline $\begin{array}{l}\text { Plow et al. } \\
2019[40]\end{array}$ & 22 & $\mathrm{RCT}$ & $\begin{array}{l}\text { CC contact-control social } \\
\text { support intervention } \\
\text { FMD physical activity plus } \\
\text { fatigue self-management } \\
\text { intervention } \\
\text { PA-only physical activity } \\
\text { only intervention }\end{array}$ & $\begin{array}{l}12 \text { week intervention } \\
12 \text { week followup. } \\
\text { Mix between group phone calls } \\
\text { and individualised phone calls. }\end{array}$ & $\begin{array}{l}208 \text { MS patients } \\
52 \text { (8) years old } \\
85 \% \text { female }\end{array}$ & $\begin{array}{l}\text { RRMS: 176, SPMS: 11, PPMS: } \\
\text { 6, PRMS: 1, unknown: } 14\end{array}$ & & $\mathrm{X}$ & & $X$ & \\
\hline $\begin{array}{l}\text { Fuchs et al. } \\
2019[41]\end{array}$ & 20 & $\begin{array}{l}\text { Experim } \\
\text { ental } \\
\text { study }\end{array}$ & BrainHQ & l & $\begin{array}{l}51 \text { MS patients } \\
56 \text { years old }\end{array}$ & $\begin{array}{c}\text { RRMS: 35, SPMS: 12, PPMS: } 4 \\
\text { EDSS: } 4[2,0 ; 6,0]\end{array}$ & & & $\mathrm{X}$ & & \\
\hline $\begin{array}{l}\text { Vilou et al. } \\
2020[42]\end{array}$ & 22 & $\begin{array}{l}\text { Explorat } \\
\text { ive } \\
\text { study }\end{array}$ & BrainHQ & $\begin{array}{c}6 \text { weeks of training } \\
(2 * 20 \mathrm{~min} / \text { week }) \\
\text { - weekly contact }+2 \text { weeks } \\
\text { scheduled visit (semi-assisted) }\end{array}$ & $\begin{array}{l}47 \text { MS patients } \\
35 \text { (16) years old } \\
85 \% \text { female }\end{array}$ & $\begin{array}{c}\text { RRMS: } 47 \\
\text { EDSS: } 3,2(2,0)\end{array}$ & & & $\mathrm{X}$ & & \\
\hline $\begin{array}{l}\text { Jeong et al. } \\
2020[43]\end{array}$ & 23 & $\begin{array}{l}\text { Retrosp } \\
\text { ective } \\
\text { analysis }\end{array}$ & MS-HAT & $\begin{array}{l}6 \text { months of follow-up } \\
2.5 \text { hours/week }\end{array}$ & $\begin{array}{l}17 \text { MS patients } \\
60(11) \text { years old }\end{array}$ & Type and EDSS not available & $\mathrm{X}$ & & $\mathrm{X}$ & & $\mathrm{X}$ \\
\hline
\end{tabular}




\begin{tabular}{|c|c|c|c|c|c|c|c|c|c|c|c|}
\hline $\begin{array}{l}\text { Kratz et al. } \\
2020[44]\end{array}$ & 24 & $\begin{array}{l}\mathrm{RCT} \\
\text { (pilot) }\end{array}$ & $\begin{array}{l}\text { Web-based and telephone } \\
\text { delivered exercises therapy }\end{array}$ & $\begin{array}{l}\text {-Home:30min endurance } 2 \mathrm{x} \\
\text { week; } 3 \mathrm{x} \text { week strength training } \\
\text { lower extremity }+2 \text { functional } \\
\text { exercises per week } \\
\text { - in-person: } 30 \text { endurance-tr }+30 \\
\text { resistance }+ \text { home exercise } \\
\text { for } 8 \text { weeks }\end{array}$ & $\begin{array}{l}20 \text { MS patients } \\
48(8) \text { years old } \\
90 \% \text { of female }\end{array}$ & RRMS: 16, SPMS: 1, PPMS: 1 & & $\mathrm{X}$ & & $\mathrm{X}$ & \\
\hline $\begin{array}{l}\text { Flachenecker } \\
\text { et al. } 2020 \\
{[45]}\end{array}$ & 23 & RCT & $\begin{array}{l}\text { Behavior-oriented exercise } \\
\text { and physical activity } \\
\text { promotion program via web } \\
\text { and telephone based } \\
\text { program }\end{array}$ & $\begin{array}{c}12 \text { weeks on intervention } \\
\text {-Strenght training (1-2 times per } \\
\text { week) } \\
\text {-Endurance training (10-60min/1- } \\
2 \text { times per week) }\end{array}$ & $\begin{array}{l}64 \text { MS patients } \\
47(9) \text { years old } \\
62 \% \text { of female }\end{array}$ & $\begin{array}{l}\text { RRMS: } 39 \text {, SPMS: } 25 \\
\text { EDSS: } 4,3[3,5 ; 5,0]\end{array}$ & $\mathrm{X}$ & & & $X$ & $\mathrm{X}$ \\
\hline $\begin{array}{c}\text { Manns et al } \\
2020[46]\end{array}$ & 22 & $\begin{array}{l}\text { Pre - } \\
\text { post } \\
\text { interven } \\
\text { tion } \\
\text { (single } \\
\text { group) }\end{array}$ & $\begin{array}{c}\text { SitLess+ MoveMore } \\
\text { FitBit on (tracking } \\
\text { instrument-self monitoring } \\
\text { tool) } \\
\text { ActivPAL3 (tracking for } \\
\text { activity level -7 day after } \\
\text { each time point) }\end{array}$ & $\begin{array}{c}15 \text { weeks of training } \\
-7 \text { weeks with SitLess } \\
\text {-weeks with MoveMore }\end{array}$ & $\begin{array}{c}41 \text { MS patients ( } 39 \text { post } \\
\text { intervention and } 36 \text { complete } \\
\text { follow-up) } \\
50(10) \text { years old } \\
90 \% \text { of female }\end{array}$ & $\begin{array}{c}\text { RRMS: 26, SPMS: 11, PPMS: } 4 \\
\text { EDSS: } 5.5 \text { (3.7) }\end{array}$ & & $X$ & & $\mathrm{X}$ & \\
\hline $\begin{array}{l}\text { Donkers et al. } \\
2020[47]\end{array}$ & 24 & $\begin{array}{l}\mathrm{RCT} \\
\text { (pilot) }\end{array}$ & $\begin{array}{l}\text { Web-based exercise } \\
\text { webbasedphysio.com }\end{array}$ & $\begin{array}{c}26 \text { weeks of training } \\
\text { Adapation of the exercises every } \\
\text { two weeks }\end{array}$ & $\begin{array}{l}48 \text { MS patients } \\
54(12) \text { years old } \\
65 \% \text { of female }\end{array}$ & Type and EDSS not available & $\mathrm{X}$ & & & & $\mathrm{X}$ \\
\hline $\begin{array}{l}\text { Messinis et } \\
\text { al. } 2020 \text { [48] }\end{array}$ & 24 & $\mathrm{RCT}$ & RehaCom & $\begin{array}{l}\text { 8weesk of training } \\
(3 * 45 \mathrm{~min} / \text { week })\end{array}$ & $\begin{array}{l}36 \text { MS patients } \\
46(4) \text { years old } \\
66 \% \text { of female }\end{array}$ & $\begin{array}{c}\text { SPMS: } 36 \\
\text { EDSS: } 5.5[4,5 ; 7,0]\end{array}$ & & & $\mathrm{X}$ & $\mathrm{X}$ & $\mathrm{X}$ \\
\hline $\begin{array}{l}\text { Minen et al. } \\
2020 \text { [49] }\end{array}$ & 23 & RCT & RELAXaHEAD & $\begin{array}{c}90 \text { days } \\
\text { Self-paced training }\end{array}$ & $\begin{array}{l}62 \text { MS patients } \\
40 \text { (10) years old } \\
89 \% \text { female }\end{array}$ & Type and EDSS not available & & & & & $\mathrm{X}$ \\
\hline $\begin{array}{l}\text { Van Geel et } \\
\text { al. } 2020[50]\end{array}$ & 25 & $\begin{array}{l}\text { Cohort } \\
\text { study }\end{array}$ & Walk-With-Me app & 10 weeks of training & $\begin{array}{c}12 \text { participants } \\
43[38,5 ; 50] \text { years old } \\
100 \% \text { female }\end{array}$ & $\begin{array}{l}\text { RRMS: } 11 \text {, SPMS: } 1 \\
\text { EDSS not available }\end{array}$ & & $\mathrm{X}$ & $\mathrm{X}$ & $\mathrm{X}$ & $\mathrm{X}$ \\
\hline $\begin{array}{l}\text { Bove et al. } \\
2020[51]\end{array}$ & 26 & $\mathrm{RCT}$ & AKL-T03 (webbased) & $\begin{array}{l}6 \text { weeks of training } \\
(5 * 25 \mathrm{~min} / \text { weeks })\end{array}$ & $\begin{array}{l}44 \text { MS patients } \\
51 \text { (13) years old } \\
80 \% \text { female }\end{array}$ & $\begin{array}{l}\text { RRMS: 33, SPMS: 7, PPMS: } 2 \text {, } \\
\text { CIS: } 1 \text {, undetermined: } 1 \\
\text { EDSS: } 3,5[2,5 ; 4,5]\end{array}$ & & & $\mathrm{X}$ & $X$ & \\
\hline $\begin{array}{l}\text { Tarakci et al. } \\
2021[52]\end{array}$ & 24 & RCT & $\begin{array}{l}\text { Web-based and telphone } \\
\text { delivered exercises therapy }\end{array}$ & $\begin{array}{l}12 \text { weeks program } \\
(3 * 60 \mathrm{~min} / \text { week })\end{array}$ & $\begin{array}{l}30 \text { MS patients } \\
41 \text { (11) years old } \\
77 \% \text { of female }\end{array}$ & $\begin{array}{c}\text { RRMS: } 30 \\
\text { EDSS: } 3,4(1,5)\end{array}$ & & $\mathrm{X}$ & & $\mathrm{X}$ & $\mathrm{X}$ \\
\hline $\begin{array}{l}\text { Williams et } \\
\text { al. } 2021[53]\end{array}$ & 23 & RCT & $\begin{array}{c}\text { Phone instruction and } \\
\text { illustrated training booklet } \\
\text { and activity diary } \\
\end{array}$ & $\begin{array}{l}8 \text { weeks of training } \\
(2 * 60 \mathrm{~min} / \text { week })\end{array}$ & $\begin{array}{l}50 \text { MS patients } \\
51(10) \text { years old } \\
76 \% \text { females } \\
\end{array}$ & $\begin{array}{c}\text { RRMS: } 31 \text {, SPMS: 6, PPMS: 7, } \\
\text { undetermined: } 6 \\
\text { EDSS not available } \\
\end{array}$ & $X$ & & & & \\
\hline
\end{tabular}

Table 2. Characteristics of the included studies on mHealth for self-assessment 


\begin{tabular}{|c|c|c|c|c|c|c|c|c|c|c|c|}
\hline \multirow[b]{2}{*}{ Study } & \multirow[b]{2}{*}{$\begin{array}{c}\text { D\&B } \\
(/ 28)\end{array}$} & \multirow[b]{2}{*}{ Study design } & \multirow[b]{2}{*}{ Intervention } & \multirow[b]{2}{*}{ Duration } & \multirow[b]{2}{*}{ Participants } & \multirow[b]{2}{*}{$\begin{array}{c}\text { Type of MS and disability } \\
\text { level }\end{array}$} & \multicolumn{5}{|c|}{ ICF } \\
\hline & & & & & & & 离 & $\sum_{\substack{0 \\
4}}^{0}$ & نี & 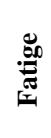 & 苛 \\
\hline $\begin{array}{l}\text { Miller et al. } \\
2011[54]\end{array}$ & 24 & $\mathrm{RCT}$ & $\begin{array}{l}\text { MCCO-enhanced (Web- } \\
\text { Based) }\end{array}$ & $\begin{array}{l}12 \text { months: self-monitoring functioning at any moment, } \\
\text { comparing MCCO-original with MCCO-enhanced }\end{array}$ & $\begin{array}{l}206 \mathrm{MS} \\
\text { patients }\end{array}$ & Not available & & & & & $X$ \\
\hline $\begin{array}{l}\text { Greiner et al. } \\
2015[55]\end{array}$ & 18 & Pilot study & $\begin{array}{l}\text { MSdialog (Web-Based } \\
\text { and App) }\end{array}$ & $\begin{array}{l}\text { 6-week study, following stages: } 5 \text {-min online survey, training } \\
\text { teleconference, weekly health reports, } 5 \text {-min usability Survey at } \\
\text { week } 3 \text { and } 6 \text {, follow-up call interview with selected patients }\end{array}$ & $\begin{array}{c}76 \mathrm{MS} \\
\text { patients } \\
68 \% \text { female }\end{array}$ & Not available & & & $\mathrm{X}$ & $\mathrm{X}$ & \\
\hline $\begin{array}{l}\text { D’Hooghe et } \\
\text { al. } 2018[56]\end{array}$ & 21 & Cohort study & $\begin{array}{l}\text { MS TeleCoach (Web- } \\
\text { Based) }\end{array}$ & $\begin{array}{c}\text { 2-week run-in period: assess baseline activity level per patient } \\
\text { 12-week period: target number of activity counts gradually } \\
\text { increased through telecoaching }\end{array}$ & $\begin{array}{l}75 \mathrm{MS} \\
\text { patients } \\
67 \% \text { female }\end{array}$ & $\begin{array}{l}\text { RRMS: } 75 \\
\text { EDSS: } 2\end{array}$ & & & & $\mathrm{X}$ & \\
\hline $\begin{array}{l}\text { Midaglia et } \\
\text { al. } 2019 \text { [57] }\end{array}$ & 20 & $\begin{array}{l}\text { Observational } \\
\text { study }\end{array}$ & Floodlight (App) & $\begin{array}{l}\text { Active monitoring for } 24 \text { weeks DMQ daily, ST: fortnightly \& } \\
\text { ad hoc, MSIS-29: fortnightly, SDMT: weekly, pinching test: } \\
\text { daily, Draw a Shape Test: daily, SBT: daily, 5UTT: daily, } \\
\text { 2MWT: daily } \\
\text { Passive monitoring: } \\
\text { gait behavior: continuous, mobility pattern: continuous }\end{array}$ & $\begin{array}{l}101 \\
\text { participants } \\
(76 \mathrm{MS} \\
\text { patients }) \\
40 \text { years old } \\
70 \% \text { female }\end{array}$ & $\begin{array}{l}\text { RRMS: } 69, \text { SPMS: } 4 \text {, } \\
\text { PPMS: } 3 \\
\text { EDSS: } 2,4(1,4)\end{array}$ & & $\mathrm{X}$ & $\mathrm{X}$ & & \\
\hline $\begin{array}{l}\text { Newland et } \\
\text { al. } 2019[58]\end{array}$ & 18 & Pilot study & $\begin{array}{l}\text { FatigueApp.com } \\
\qquad(\text { App) }\end{array}$ & $\begin{array}{l}\text { FatigueApp.com: collect data for } 5 \text { weeks on Patient-Reported } \\
\text { Outcomes Measurement Information System (PROMIS) }\end{array}$ & $\begin{array}{c}32 \mathrm{MS} \\
\text { patients } \\
49(11) \\
\text { years old } \\
81 \% \text { female }\end{array}$ & $\begin{array}{l}\text { RRMS: } 30, \text { SPMS: } 2 \\
\text { EDSS: } 3[2 ; 4,8]\end{array}$ & & & & $\mathrm{X}$ & \\
\hline $\begin{array}{l}\text { Pratap et al. } \\
2020[59]\end{array}$ & 21 & $\begin{array}{l}\text { Observational } \\
\text { pilot study }\end{array}$ & ElevateMS (App) & $\begin{array}{c}12 \text { weeks } \\
\text { Completed baseline assessments, including self-reported } \\
\text { physical ability and longitudinal assessments of quality of life } \\
\text { and daily health } \\
\text { Completed functional tests as an independent assessment of } \\
\text { MS- related motor activity }\end{array}$ & $\begin{array}{c}629 \\
\text { participants } \\
(490 \mathrm{MS} \\
\text { patients) } \\
47(11) \\
\text { years old } \\
50 \% \text { female }\end{array}$ & $\begin{array}{l}\text { RRMS: 423, SPMS: } 30 \text {, } \\
\text { PPMS: } 42 \text {, undetermined: } 2\end{array}$ & & $\mathrm{X}$ & & & $\mathrm{X}$ \\
\hline
\end{tabular}

D\&B: Downs and Black checklist 


\subsection{Quality assessment}

The quality of the included papers was checked using the Downs and Black checklist. Overall, the average score for the included studies is 21.9 out of 28 (22.2 for studies on rehabilitation, 20.3 for studies assessing self-assessment). The average results for the different questions and sub-analysis of the Downs and Black checklist are presented in Figure 2.

When analyzing individual items, we observed that, due to the nature of the training, the blinding of the participants was not possible, on the other hand, the blinding of the investigators was not guaranteed either. Another potential source of bias is the uncertainty about the randomization assignment until the complete recruitment. The last important point is that a high number of studies do not take into consideration the patients that did not complete the intervention (loss in follow-up) so leading to uncertainty on reasons of non-adherence. Only a few studies used intention-to-treat analysis. On average $90.6 \%$ of the included patients completed the entire protocol and were included in the final analysis.



Figure 2. Quality of the study, author's judgment broken down for each question of the Downs and Black checklist across all included studies (IV: internal validity, for the question about the data dredging the green color indicates that there is no problem and data were acquired directly and have not been imputed).

\subsection{Description of the available mHealth solutions}

First, we will present the mHealth solutions that are mainly used for rehabilitation purposes. Most of the proposed mHealth solutions have been studied for cognition, QoL, and fatigue and were limited to one single ICF domain. We will discuss the applications for the respective domains, although some overlap occurred.

RehaCom $[24,30,33,48]$ is a comprehensive and sophisticated system of software for computer-assisted cognitive rehabilitation. It proposes different solutions for screening and training cognitive functions and offers apps for home training.

BrainHQ [32,41,42] is a platform providing a set of more than 30 mini brain training exercises designed to challenge different cognitive functions (processing speed, attention, working memory, and executive function through visual and auditory domains). The initial level of challenge is low and the difficulty is adapted on an individual basis as learning and abilities improve over time. The company was previously known as Posit Sciences [27].

Luminosity [25] is a platform providing cognitive training exercises embedded in games. As for BrainHQ different cognitive functions can be challenged in a set of different mini-games. 
The MAPSS-MS intervention [35] aims to help persons with MS acquire the highest level of cognitive functioning and functional independence. It includes problems solving and lifestyle adjustments (sleep, stress management, physical activity) that support cognitive functioning and will support persons with MS in the use of compensatory cognitive strategies and cognitive skills. The cognitive training is done with Luminosity app.

BrainStim [28] is a computerized training tool based on the working memory (WM) model of Baddeley [60]. It consists of three different modules targeting both, verbal and visual-spatial aspects of WM.

COGNI-TRAcK [31] implements three different types of exercises which were shown to be effective in improving the cognitive status of healthy subjects. The exercises consisted in: (i) a visuospatial WM task; (ii) an "operation" N-back task ; (iii) a "dual" Nback task [61].

The Attention Processing training (APT) program [25] is a cognitive rehabilitation intervention that targets focused, sustained, selective, alternating, and divided attention. The aim is to increase the ability to respond to specific stimuli [62].

ELEVEDIA [37] content is based on cognitive behavioral therapy strategies and is conveyed chiefly via the technique of a 'simulated dialogue'. Program modules are composed of an introduction and a summary and include homework tasks. Patients are advised to access the program once to twice per week.

MS HAT system [34,43] is supporting patient-centered care, self-management and allows easier patient-provider communication. Three interfaces are available: patient unit, server, and clinical unit. The patient unit had interactive options for data collection, educational content, exercise information, and therapist-patient communication Access to exercises, respond to exercise-specific assessments, and document exercise data from home. Exercises consist of task-oriented training such as digitized writing tracking or manipulating light bulbs or keys. Exercise adherence feedback via diary entries, calendars, and graphs [63].

AKL-TO3 [51] is engaging the patients in simultaneous sensory and motor tasks and is designed to engage the frontal neural network. It enabled real-time monitoring of progress and continuously challenges patients so that the training is never too easy or difficult encouraging patients to improve performance.

RELAXaHEAD [49] is designed for pain management and in particular migraine and neck pain. It contained a headache diary, which includes features for tracking headache characteristics, headache medications and sleep, and tracking medication side effects and menstrual cycles. The app also contains a serious game module to ease muscle relaxation.

WalkWithMe [50] has been developed to motivate and stimulate patients to walk more and farther. It allows to track the walking activities and follow up on progress. The app detects the walking speed and gives feedback during walking with verbal feedback (i.e., pace) by the virtual coach.

Webbasedphysio.com [47] is an internet-delivered therapeutic exercise program. The web-based physio allows people the flexibility to do their own, individualized exercise program at a time and location which is convenient to them, thus enhancing the individual's ability to self-manage their condition on a long term basis.

Deprexis [29] is an online program based on principles of cognitive-behavioral therapy. It consists of ten sequential modules - psycho-education, behavioral activation, cognitive modification, mindfulness and acceptance, interpersonal skills, relaxation, physical exercise and lifestyle modification, problem-solving, expressive writing and forgiveness, positive psychology, and emotion-focus interventions.

MBSR [38] dealt with stress management, relaxation training, sleep hygiene, fatigue, and social relationships. The course materials were developed using existing informative MS videos, created by the Italian MS Association; recording new interviews; and generating new exercises. 
Concerning the mHealth apps that are mainly used for self-assessment;

MSdialog [55] is a web- and mobile (i.e., cell phone and tablet) based software application that combines information from RebiSmart (with health information recorded by patients via their personal computer or smartphone to collect and store real-time data regarding administration, clinical outcomes, and patients reported outcomes. MSdialog offers a practical means by which patients record and exchange information with their healthcare specialists intending to support the patient-physician relationship and offering patients a method of engaging in the management of their MS [64].

MS Telecoach [56] provides a combination of monitoring, self-management, and motivational messages, focusing on energy management of physical activity to improve fatigue levels. Two components: telemonitoring (physical activity through accelerometers and self-reported fatigue impact levels) and tele-coaching (motivational messages and advice).

Floodlight [57] is a combination of continuous sensor data capture and standard clinical outcome measures. Performing a set of daily active tests to evaluate cognition, upper extremity function, gait, and balance domains and contribute sensor data via passive monitoring, also including self-reported patient outcomes.

MCCO-enhanced [54] is an electronic messaging system between clinician and patient. It contains a self-monitoring and self-management system to assess MS symptoms and the pwMS receives graphical feedback to evaluate symptom changes

FatigueApp.com [58] is collecting data to correlate fatigue measures with other symptoms and quality. Self-reporting symptoms. Completing fatigue questionnaires every morning for 6 consecutive days and again 4 weeks later.

ElevateMS [59] allows collecting different data in the real-world environment of the patients such as self-reported measures of symptoms and health via 'check-in'-surveys Independent assessments of motor function via sensor-based active functional tests Encouraging to complete surveys daily and notifications to perform more comprehensive functional tests once a week.

\subsection{Outcome data related to ICF}

\subsubsection{Rehabilitation}

Amongst the included RCTs, 20 were included in the meta-analysis assessing the efficacy of mHeath for rehabilitation [24,26-31,33-37,39,40,44,45,47-49,51,65], representing 1,393 pwMS. When considering all the studies and ICF domains together, the heterogeneity between the studies was moderate $\left(\operatorname{tau}^{2}=0.30,95 \% \mathrm{CI}[0.26 ; 0.62]\right)$, therefore we decided to use random-effect model. The funnel plot did not show significant asymmetry (Egger's intercept $=0.45, \mathrm{p}=0.91)$ (Figure $\mathrm{S} 1)$. The sensitivity analysis did not show any outlier (Figure S2).

The overall effect of mHealth intervention in pwMS is moderate (SMD $=0.50[0.35$; $0.66])$ and statistically significant $(p<.0001)$. since different studies evaluated human functioning at different aspects according to the ICF, we then performed subgroup analysis to assess the efficacy across the different ICF. The forest plot is presented in Figure 3.

At the ICF domains level, we observed the biggest effect for fatigue (SMD $=0.61[0.47$ $; 0.76])$, followed by outcome measures at the the activity level (SMD $=0.56[0.25 ; 0.87])$, and cognitive impairment (SMD $=0.28[0.12 ; 0.45])$. Note that for activity level these results must be interpreted carefully due to the small number of included studies $(n=3)$ For the domains of motor function and quality of life the results were not significant but only included 2 and 3 studies respectively. Using a fixed-effect model to summarize the overall ICF functioning we found an overall moderate effect (SMD $0.47[0.37 ; 0.56], \mathrm{p}<$ $.0001)$. 


\section{Subgroup}

Activity level

Conroy et al, 2018

Kratz et al, 2020

Plow et al, 2019

Random effects model

$I^{2}=0 \%[0 \% ; 90 \%], \quad 2=0.32(p=0.85)$

Cognition

Bove et al, 2020

Campbell et al. 2016

Cerasa et al. 2012

Charvet et al, 2017

Charvet et al. 2015

Chiaravalloti et al, 2018

Hancock et al. 2015

Hubacher et al. 2015

Messinis et al, 2020

Messinis et al. 2017

Pedullà et al. 2016

Stuifbergen et al, 2018

Random effects model

$I^{2}=4 \%[0 \% ; 60 \%], \quad 2=11.47(p=0.40)$

\section{Fatigue}

Bove et al, 2020

Cerasa et al. 2012

Fischer et al. 2015

Fjeldstad-Pardo et al, 2018

Flachenecker et al, 2020

Kratz et al, 2020

Messinis et al, 2020

Plow et al, 2019

Pöttgen et al. 2018

Random effects model

$I^{2}=7 \%[0 \% ; 67 \%], \quad 2=8.62(p=0.37)$

\section{Motor function}

Conroy et al, 2018

Williams et al, 2021

Random effects model

$I^{2}=0 \%, \quad 1=0.03(p=0.85)$

Quality of Life

Fischer et al. 2015

Messinis et al, 2020

Minen et al, 2020

Random effects model

$I^{2}=69 \%[0 \% ; 91 \%], \quad 2=6.46(p=0.04)$

Fixed effects (plural) model

$I^{2}=31 \%[0 \% ; 56 \%], \quad 4=12.46(p=0.01)$

\section{Standardised Mean} Difference

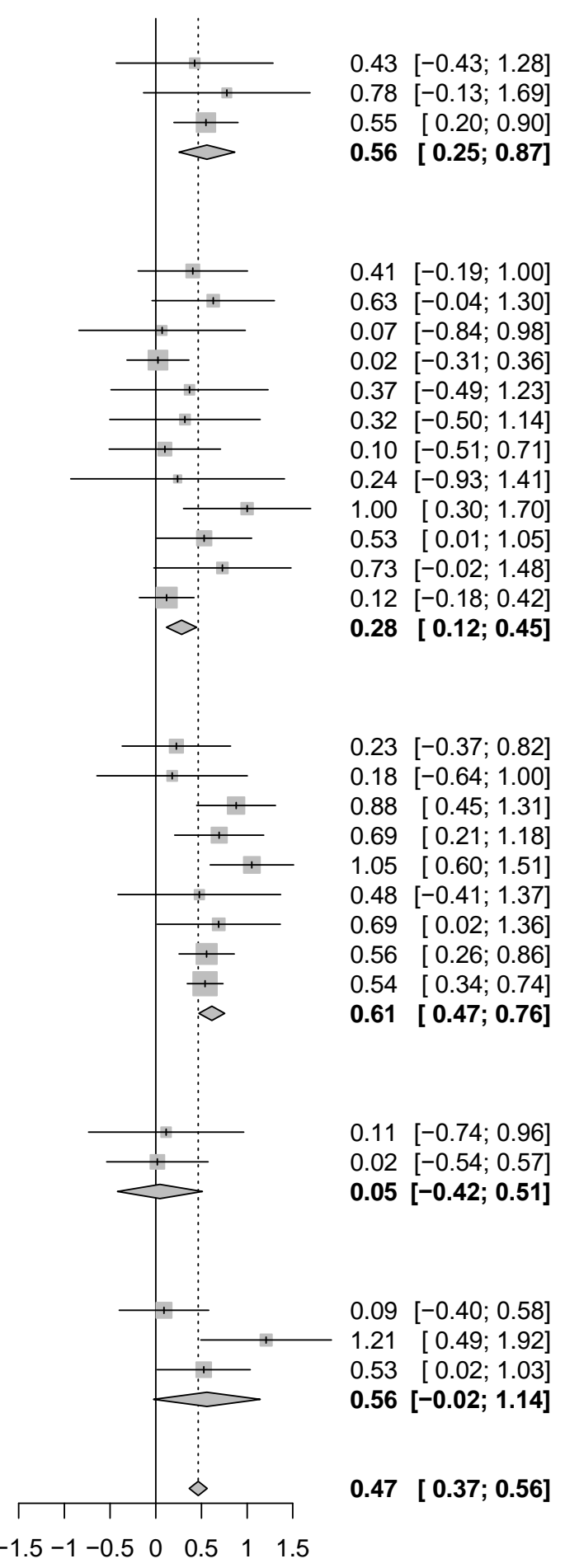

Figure 3. Stratified meta-analysis according to ICF domains. Positive SMD indicates superior efficacy of the mHealth intervention compared to control group. 
We then summarized the main results and conclusions of the studies that were not included in the meta-analysis.

Concerning cognitive function, Fuchs et al. 2019 investigated the clinical characteristics predicting response to a home-based restorative cognitive training. Significant improvements were observed after training [41]. Villou et al. 2020 is an explorative study reported statistical improvement of various cognitive functions such as visuospatial memory, visual attention, task-switching, reading speed and response inhibition, and verbal learning [42].

For fatigue, Stuifenbergen et al. 2018 analyzed the acceptability and effect of MAPSSMS on cognitive function and fatigue. The authors find similar results than with usual care, interestingly the improvements were maintained during the follow-up at 3 and 6 months and were superior in the intervention group [35].

For the quality of life, Cavalera et al. 2018 showed an improvement of QoL after 8 weeks of intervention using a mindfulness program but the progress was not maintained over time (6-month follow-up after the end of the intervention) [38]. Tarakci et al. 2021 compared an in-person rehabilitation program with a telerehabilitation program. After 12 weeks of training, the results were similar in the two groups for fatigue and activity level [52]. Manns et al. 2020 demonstrated a reduction of fatigue after a combined intervention (SitLess and MoveMore) but the difference was not significant compared to usual care [46]. Interestingly the total sedentary time decreased in the intervention group and these results are maintained over time.

Van Geel et al reported that using the WalkWithMe app induced a significant improvement in quality of life, walking, and leisure, 36-Item Short-Form Health Survey (SF-36) quality of life, cognition, cognitive fatigability, lower limb strength, and dominant hand function. However, it was an observational study without a control group [50].

\subsubsection{Self-assessment}

Concerning the efficacy of self-assessment and monitoring only 6 studies were included in this review.

Miller et al. highlighted group differences between the MCCO-original and MCCOenhanced groups. MCCO-original had a higher European Quality of Life level after 12 months of regularly self-monitoring their quality of life [54].

Greiner et al. performed a six-week longitudinal observation and showed that MSdialog was adapted to monitor patient-reported outcomes. Amongst the different functions evaluated by the pwMS, fatigue (99\%), physical health (96\%), cognitive deficits $(93 \%)$, pain $(91 \%)$ and sleep quality $(91 \%)$ were the most important. These numbers represent the weight given by the patients for these different functions that scored the MS quality-of-life questionnaire using a visual analogical scale [55].

D'Hooghe et al. showed that it is feasible to use the MS TeleCoach at home without supervision. The authors observed a significant decrease in fatigue and an increase in cognitive function after 12 weeks of use. [56].

Midaglia et al. assessed the usability and acceptability of the Floodlight for active monitoring and passive monitoring intervention. After 24 weeks of intervention, mHealth had an acceptable impact on daily activities including cognition and physical activity for $80 \%$ of the pwMS [57].

Newland et al. reported that the FatigueApp could collect self-reported symptoms including fatigue, self-reported EDSS (EDSS-SR), pain, and cognition [58]. Participants were asked to complete the questionnaires for 7 consecutive days and then again 4 weeks later.

Pratap et al. in a large study including more than 500 pwMS described that ElevateMS can be used to longitudinally (12 weeks period) collect formation about the most common symptoms of MS. During this follow-up, they observed that the most frequent complaints are fatigue $(63 \%)$, memory issues $(42 \%)$ and difficulty with walking (41\%). After the intervention, there were significant increased functional performances and QoL [59]. 
To summarize the findings of this study we listed the different mHealth according to the targeted ICF domain for both rehabilitation and self-assessment in Table 3.

Table 3: Overview of the different mHealth solutions for rehabilitation and self-assessment

\begin{tabular}{|c|c|c|}
\hline \multirow{2}{*}{$\begin{array}{l}\text { Functioning } \\
\text { (ICF) }\end{array}$} & \multicolumn{2}{|c|}{ mHealth } \\
\hline & Rehabilitation & Self-assessment \\
\hline Cognition & $\begin{array}{c}\text { BrainHQ }[27,32,39,41,42] \\
\text { Lumosity [26] } \\
\text { RehaCom [24,30,33] } \\
\text { BrainStim [28] } \\
\text { COGNI-TRAcK [31] } \\
\text { MAPPS-MS* [35] } \\
\text { APT [25] } \\
\text { MS-HAT [43] } \\
\text { Walk-With-Me [50] } \\
\text { AKL-T03 [51] }\end{array}$ & $\begin{array}{l}\text { MSdialog [55] } \\
\text { Floodlight [57] }\end{array}$ \\
\hline Fatigue & $\begin{array}{c}\text { RehaCom [24,33] } \\
\text { ELEVEDIA [37] } \\
\text { MAPPS-MS [35] } \\
\text { SitLess \& MoveMore [46] } \\
\text { Walk-With-Me [50] } \\
\text { AKL-T03 [51] }\end{array}$ & $\begin{array}{c}\text { MSdialog [55] } \\
\text { MS TeleCoach [56] } \\
\text { FatigueApp.com [58] }\end{array}$ \\
\hline Quality of Life & $\begin{array}{c}\text { ELEVEDIA [37] } \\
\text { MBSR [38] } \\
\text { MS-HAT [43] } \\
\text { webbasedphysio.com [47] } \\
\text { RehaCom [48] } \\
\text { RELAXaHEAD [49] } \\
\text { Walk-With-Me [50] }\end{array}$ & $\begin{array}{l}\text { MCCO-enhanced [54] } \\
\text { ElevateMS [59] }\end{array}$ \\
\hline Activity Level & $\begin{array}{c}\text { MS-HAT system [34] } \\
\text { SitLess \& MoveMore [46] } \\
\text { Walk-With-Me [50] }\end{array}$ & $\begin{array}{l}\text { Floodlight [57] } \\
\text { ElevateMS [59] }\end{array}$ \\
\hline Motor Function & $\begin{array}{l}\text { MS-HAT system }[34,43] \\
\text { webbasedphysio.com }[47]\end{array}$ & l \\
\hline
\end{tabular}

* The cognitive training module of MAPPS-MS is done with Luminosity.

\section{Discussion}

The main result of this review is the high number of solutions (applications) currently being tested with pwMS for rehabilitation $(n=16)$, despite the relatively recent development and use of these new apps in rehabilitation. On another side, the development of mHealth for self-assessment and home-monitoring is still limited (6 apps found). Consequently, one of the downsides is that there are only a very few studies performed with the same mHealth which makes it more difficult to compare the studies and thus to determine the level of evidence. Therefore, rather than comparing the efficacy of each particular mHealth, we performed the analysis at the ICF domain level. The most studied ICF domain is cognition: we found a small but significant effect of the training using mHealth $(\mathrm{SMD}=0.28[0.12 ; 0.45])$ which is consistent with other meta-analysis summarizing the effect of computerized cognitive training, including computer solutions and supervised training $(\mathrm{SMD}=0.30[0.18 ; 0.43])[66]$. The second most studied function is fatigue, with a moderate effect (SMD $=0.61[0.47 ; 0.76])$. The effect of mHealth is a bit lower than the effect of pharmacological treatment (i.e., amantadine): SMD $=1.09$ [0.87 ; 1.30] [67], but similar to the effect of exercise therapy (SMD $=0.53$ [0.33;0.73]) [68].

For the motor function and quality of life, there are, currently, not enough studies available, but the few studies available also seem to indicate a favorable effect. The paucity of studies investigating the effects of mHealth applications to train motor functions is somehow surprising. However, we excluded studies including wearables and thus the number of interventions done to increase physical activity based on step count (i.e., [69]). The low numbers of studies investigating the effects of mHealth interventions on quality of life may be expected as the quality of life is often thought to be the result of improving specific ICF domains. 
Another major finding of this study regarding self-assessment is the fact that mHealth can be used directly by the patients to continuously monitor several different functions in their living environment. The solutions are not only well accepted by the patients but several studies also show that using this type of mHealth is directly beneficial for the patients. This positive effect may be mediated by a better knowledge of the diseases and symptoms (education) [70] but also by the more active participation of the patient in his treatment (patients engagement) [71].

There are several limitations to this review. The first one is the lack of standardization in the nomenclature used to describe the different mHealth currently tested in research. Therefore, due to the small numbers of studies published, we ended-up in including studies assessing different types of applications and intervention modalities or duration. The heterogeneity between the studies, and the patients, makes it more difficult to compare studies and especially to generalize the results. A second important limitation is that most of the included studies on the rehabilitation aspects (except $[32,35,38,40,45]$ ) have relatively small sample sizes and the results are likely to be underpowered [72]. Furthermore, the percentage of participants that were included in the final analysis is $90 \%$ and information about the adherence to the intervention was missing (usually a threshold of $80 \%$ is applied to determine if the participants do a sufficient amount of exercises [73]). Concerning the meta-analysis, due to the relatively small number of included studies, the results must also be interpreted carefully, especially for the ICF motor function and quality of life. Concerning motor functions, most of the current solutions are focusing on walking while patients may also experiment severe disability in upper limbs functions and dexterity, efforts must be made to develop solutions that focus on these problems. Concerning the external validity of this study and the translation to the research, it is important to note that the vast majority of the applications were tested in pwMS with mild disability (EDSS $=3.5 \pm 1.1$ ), and thus not guaranteed to be applicable to the same extent in more disabled patients. Further studies must therefore focus on more disabled patients to determine the feasibility of mHealth with these patients if the efficacy is similar.

Finally, the solutions presented are still at the research project stage and applications are not yet widely available to patients or their treating clinicians.

Despite these limitations, this study highlights interesting and promising results for patients. However, there are still a few points that should be addressed before these solutions can be used in daily practice. The first, and probably most important is the recognition of the $\mathrm{m}$ - and eHealth apps as medical devices. In June 2020, the U.S. Food and Drug Administration (FDA) permitted the marketing of the first game-based digital therapeutic device to improve attention function in children with attention deficit hyperactivity disorder (ADHD). The mHeath, EndeavorRx, is indicated to improve attention function as measured by computer-based testing and is the first digital therapeutic intended to improve symptoms associated with ADHD, as well as the first game-based therapeutic granted marketing authorization by the FDA for any type of condition. The device is intended for use as part of a therapeutic program that may include clinician-directed therapy, medication, and/or educational programs, which further address symptoms of the disorder [74]. Interestingly this solution is developed by Akili, the company that has developed AKL-T03 which also shows significant results in pwMS [51]. The COVID-19 pandemic has not only disrupted health care systems but has also allowed for a very significant acceleration in the development, implementation, and recognition of mHealth in the clinics [75]. It is important to note, however, that most of the measures taken during the crisis may be temporary and it is hoped that efforts will continue in this direction once the crisis is over. For example, it will be important to adapt the nomenclature of interventions, as mobile solutions are currently placed in the same categories as drugs, which poses problems for the validation and reimbursement of these interventions [76]. Another limitation is that, for the moment, the majority of the analyzed mHealth is being developed during research projects and is therefore not easily accessible for patients, except for BrainHQ and Luminosity that are two commercial (gaming) companies. As an indication, the price of an annual subscription to these companies is less 
than $\$ 100$ per year for a full premium account. RehaCom is also already widely used by clinical centers but mostly for research purposes.

This brings us to the second biggest current limitation which is the lack of reimbursement by the social security system. The organization and involvement of health care systems in the revalidation process is country-specific and we will not discuss reimbursement specifically here. However, we know that two of the most important barriers to the implementation of telemedicine and telehealth for the patients, regardless of the pathologies or the specialties, are the financial issues and the lack of knowledge and familiarity with the use of (new) technology [77,78]. The pwMS being relatively young, most of them are familiar with smartphones, apps, and mobile technology, therefore the familiarity with the technology should not be an issue for most of the patients [79], but this can be a real barrier for other diseases or patient group (e.g., older adults with dementia) [80]. Efforts must also been done in the education of healthcare professional as they need to be perfectly aware of the technology and their limitations to motivate the patients to use it.

As a result of all the above limitations, in practice, the solutions described in this article are only used by a small fraction of the pwMS. A recent survey performed in the US found that only $3.1 \%$ of the pwMS who took part in the survey $(n=786)$ are using mHealth solutions regularly [81].

We will now discuss some ideas for consideration to facilitate the implementation of these solutions in the rehabilitation process.

The first point would be to integrate the mHealth solutions into the health care system, with reimbursement for the patients, a better education of the healthcare professionals, and the integration of the data collected with the apps (see [54-59]) in patients' medical records. This could speed up and ease the implementation of mHealth in the daily management and rehabilitation of pwMS is. This would not only save time but also allow for a more accurate and regular assessment of patients [65]. Furthermore, these assessments could be carried out in the patients' homes. This fits in perfectly with telemonitoring [82] and the use of real-world data [83].This would therefore allow the development (by increasing the number of potential users, companies may be more inclined to invest in such solutions;) and wider use of these solutions.

A last important point is the sustainability of the studied solutions [84]. The speed of the development of mobile technology (hardware and software) is one of the most important and the technology is quickly obsolete (for example there is a new version of the operating systems [Andoid $\odot$ or iOS@] average every 6 months). Thus, the apps that have been developed with the previous version are not supported anymore with the more recent one. This is not much of an issue with the commercial solution but it is more problematic with the solution being developed during research projects.

\section{Conclusions}

This study highlights an important potential of mHealth for pwMS with evidence of small but significant effect on fatigue and cognition. Although we have seen that current mHealth is, at the moment, not a perfect solution, given the high prevalence of fatigue and cognitive impairment in pwMS and the lack of low-cost tools to assist and stimulate the patients at home, the use of apps could be greatly beneficial.

To develop innovative, effective solutions adapted for pwMS whose cognition, quality of life, functionality, and wellbeing are impaired, researchers, clinicians, policy makers, and app developers will need to further collaborate. 
Supplementary Materials: The following are available online at www.mdpi.com/xxx/s1,

Table S1: Search strategy for PubMed

Figure S1: Funnel plot of the included studies in the meta-analysis

Figure S1: Sensitivity analysis of the included studies in the meta-analysis

Author Contributions: “Systematic Review, B.B., A.R, P.F.; formal analysis, B.B., P.F.; writingoriginal draft preparation, B.B..; writing - review and editing, B.B., A.R., A.S. I.L., P.F.; visualization, B.B..; supervision, P.F., A.R., I.L.; project administration, P.F. All authors have read and agreed to the published version of the manuscript."

Funding: This research received no external funding.

Institutional Review Board Statement: NA.

Informed Consent Statement: NA.

Data Availability Statement: NA.

Acknowledgments: The authors would like to thanks Ms. Deschryvere Charlotte, Noels Maite, and Roesner Marianna for their precious help in the search and inclusion of articles.

Conflicts of Interest: The authors declare no conflict of interest. 


\section{References}

1. Papanicolas, I.; Mossialos, E.; Gundersen, A.; Woskie, L.; Jha, A.K. Performance of UK National Health Service Compared with Other High Income Countries: Observational Study. BMJ 2019, 367, 16326, doi:10.1136/bmj.16326.

2. Flachenecker, P.; Buckow, K.; Pugliatti, M.; Kes, V.B.; Battaglia, M.A.; Boyko, A.; Confavreux, C.; Ellenberger, D.; Eskic, D.; Ford, D.; et al. Multiple Sclerosis Registries in Europe - Results of a Systematic Survey. Mult Scler 2014, 20, 1523-1532, doi:10.1177/1352458514528760.

3. WHO Fact Sheets: Rehabilitation; 2020;

4. Statista Number of Smartphone Users Worldwide from 2016 to 2026 Available online: https://www.statista.com/statistics/330695/number-of-smartphone-users-worldwide/.

5. Anderson, K.; Burford, O.; Emmerton, L. Mobile Health Apps to Facilitate Self-Care: A Qualitative Study of User Experiences. PLoS One 2016, 11, e0156164, doi:10.1371/journal.pone.0156164.

6. Birkhoff, S.D.; Smeltzer, S.C. Perceptions of Smartphone User-Centered Mobile Health Tracking Apps Across Various Chronic Illness Populations: An Integrative Review. J Nurs Scholarsh 2017, 49, 371-378, doi:10.1111/jnu.12298.

7. Hernandez Silva, E.; Lawler, S.; Langbecker, D. The Effectiveness of MHealth for Self-Management in Improving Pain, Psychological Distress, Fatigue, and Sleep in Cancer Survivors: A Systematic Review. J Cancer Surviv 2019, 13, 97-107, doi:10.1007/s11764-018-0730-8.

8. Zheng, C.; Chen, X.; Weng, L.; Guo, L.; Xu, H.; Lin, M.; Xue, Y.; Lin, X.; Yang, A.; Yu, L.; et al. Benefits of Mobile Apps for Cancer Pain Management: Systematic Review. JMIR Mhealth Uhealth 2020, 8, e17055, doi:10.2196/17055.

9. Kapoor, A.; Nambisan, P.; Baker, E. Mobile Applications for Breast Cancer Survivorship and Self-Management: A Systematic Review. Health Informatics J 2020, 26, 2892-2905, doi:10.1177/1460458220950853.

10. Xu, H.; Long, H. The Effect of Smartphone App-Based Interventions for Patients With Hypertension: Systematic Review and Meta-Analysis. JMIR Mhealth Uhealth 2020, 8, e21759, doi:10.2196/21759.

11. Giebel, G.D.; Gissel, C. Accuracy of MHealth Devices for Atrial Fibrillation Screening: Systematic Review. JMIR Mhealth Uhealth 2019, 7, e13641, doi:10.2196/13641.

12. Bateman, D.R.; Srinivas, B.; Emmett, T.W.; Schleyer, T.K.; Holden, R.J.; Hendrie, H.C.; Callahan, C.M. Categorizing Health Outcomes and Efficacy of MHealth Apps for Persons With Cognitive Impairment: A Systematic Review. J Med Internet Res 2017, 19, e301, doi:10.2196/jmir.7814.

13. Elavsky, S.; Knapova, L.; Klocek, A.; Smahel, D. Mobile Health Interventions for Physical Activity, Sedentary Behavior, and Sleep in Adults Aged 50 Years and Older: A Systematic Literature Review. J Aging Phys Act 2019, 27, 565-593, doi:10.1123/japa.2017-0410.

14. Rintala, A.; Hakala, S.; Paltamaa, J.; Heinonen, A.; Karvanen, J.; Sjögren, T. Effectiveness of Technology-Based Distance Physical Rehabilitation Interventions on Physical Activity and Walking in Multiple Sclerosis: A Systematic Review and Meta-Analysis of Randomized Controlled Trials. Disabil Rehabil 2018, 40, 373-387, doi:10.1080/09638288.2016.1260649.

15. Marziniak, M.; Brichetto, G.; Feys, P.; Meyding-Lamadé, U.; Vernon, K.; Meuth, S.G. The Use of Digital and Remote Communication Technologies as a Tool for Multiple Sclerosis Management: Narrative Review. JMIR Rehabil Assist Technol 2018, 5, e5, doi:10.2196/rehab.7805.

16. Moher, D.; Liberati, A.; Tetzlaff, J.; Altman, D.G. Preferred Reporting Items for Systematic Reviews and MetaAnalyses: The PRISMA Statement. Journal of Clinical Epidemiology 2009, 62, 1006-1012, doi:10.1016/j.jclinepi.2009.06.005.

17. Downs, S.H.; Black, N. The Feasibility of Creating a Checklist for the Assessment of the Methodological Quality Both of Randomised and Non-Randomised Studies of Health Care Interventions. J Epidemiol Community Health 1998, 52, 377-384, doi:10.1136/jech.52.6.377.

18. Deeks, J.J.; Dinnes, J.; D’Amico, R.; Sowden, A.J;; Sakarovitch, C.; Song, F.; Petticrew, M.; Altman, D.G.; International Stroke Trial Collaborative Group; European Carotid Surgery Trial Collaborative Group Evaluating Non-Randomised Intervention Studies. Health Technol Assess 2003, 7, iii-x, 1-173, doi:10.3310/hta7270.

19. Higgins, J.P.T.; Thomas, J.; Chandler, J.; Cumpston, M.; Li, T.; Page, M.; Welch, V. Cochrane Handbook for Systematic Reviews of Interventions, 2nd Edition; Wiley-Blackwell.; 2019; ISBN 978-1-119-53662-8.

20. Carter, E.C.; Schönbrodt, F.D.; Gervais, W.M.; Hilgard, J. Correcting for Bias in Psychology: A Comparison of Meta-Analytic Methods. Advances in Methods and Practices in Psychological Science 2019, 2, 115-144, doi:10.1177/2515245919847196. 
21. Sterne, J.A.C.; Sutton, A.J.; Ioannidis, J.P.A.; Terrin, N.; Jones, D.R.; Lau, J.; Carpenter, J.; Rücker, G.; Harbord, R.M.; Schmid, C.H.; et al. Recommendations for Examining and Interpreting Funnel Plot Asymmetry in MetaAnalyses of Randomised Controlled Trials. BMJ 2011, 343, d4002, doi:10.1136/bmj.d4002.

22. Pustejovsky, J.E.; Rodgers, M.A. Testing for Funnel Plot Asymmetry of Standardized Mean Differences. Res Synth Methods 2019, 10, 57-71, doi:10.1002/jrsm.1332.

23. Liberati, A.; Altman, D.G.; Tetzlaff, J.; Mulrow, C.; Gøtzsche, P.C.; Ioannidis, J.P.A.; Clarke, M.; Devereaux, P.J.; Kleijnen, J.; Moher, D. The PRISMA Statement for Reporting Systematic Reviews and Meta-Analyses of Studies That Evaluate Health Care Interventions: Explanation and Elaboration. PLOS Medicine 2009, 6, e1000100, doi:10.1371/journal.pmed.1000100.

24. Cerasa, A.; Gioia, M.C.; Valentino, P.; Nisticò, R.; Chiriaco, C.; Pirritano, D.; Tomaiuolo, F.; Mangone, G.; Trotta, M.; Talarico, T.; et al. Computer-Assisted Cognitive Rehabilitation of Attention Deficits for Multiple Sclerosis: A Randomized Trial With FMRI Correlates. Neurorehabil Neural Repair 2013, 27, 284-295, doi:10.1177/1545968312465194.

25. Amato, M.; Goretti, B.; Viterbo, R.; Portaccio, E.; Niccolai, C.; Hakiki, B.; Iaffaldano, P.; Trojano, M. ComputerAssisted Rehabilitation of Attention in Patients with Multiple Sclerosis: Results of a Randomized, Double-Blind Trial. Mult Scler 2014, 20, 91-98, doi:10.1177/1352458513501571.

26. Charvet, L.; Shaw, M.; Haider, L.; Melville, P.; Krupp, L. Remotely-Delivered Cognitive Remediation in Multiple Sclerosis (MS): Protocol and Results from a Pilot Study. Multiple Sclerosis Journal - Experimental, Translational and Clinical 2015, 1, 205521731560962, doi:10.1177/2055217315609629.

27. Hancock, L.M.; Bruce, J.M.; Bruce, A.S.; Lynch, S.G. Processing Speed and Working Memory Training in Multiple Sclerosis: A Double-Blind Randomized Controlled Pilot Study. Journal of Clinical and Experimental Neuropsychology 2015, 37, 113-127, doi:10.1080/13803395.2014.989818.

28. Hubacher, M.; Kappos, L.; Weier, K.; Stöcklin, M.; Opwis, K.; Penner, I.-K. Case-Based FMRI Analysis after Cognitive Rehabilitation in MS: A Novel Approach. Front. Neurol. 2015, 6, doi:10.3389/fneur.2015.00078.

29. Fischer, A.; Schröder, J.; Vettorazzi, E.; Wolf, O.T.; Pöttgen, J.; Lau, S.; Heesen, C.; Moritz, S.; Gold, S.M. An Online Programme to Reduce Depression in Patients with Multiple Sclerosis: A Randomised Controlled Trial. Lancet Psychiatry 2015, 2, 217-223, doi:10.1016/S2215-0366(14)00049-2.

30. Campbell, J.; Langdon, D.; Cercignani, M.; Rashid, W. A Randomised Controlled Trial of Efficacy of Cognitive Rehabilitation in Multiple Sclerosis: A Cognitive, Behavioural, and MRI Study. Neural Plasticity 2016, 2016, 1-9, doi:10.1155/2016/4292585.

31. Pedullà, L.; Brichetto, G.; Tacchino, A.; Vassallo, C.; Zaratin, P.; Battaglia, M.A.; Bonzano, L.; Bove, M. Adaptive vs. Non-Adaptive Cognitive Training by Means of a Personalized App: A Randomized Trial in People with Multiple Sclerosis. J NeuroEngineering Rehabil 2016, 13, 88, doi:10.1186/s12984-016-0193-y.

32. Charvet, L.E.; Yang, J.; Shaw, M.T.; Sherman, K.; Haider, L.; Xu, J.; Krupp, L.B. Cognitive Function in Multiple Sclerosis Improves with Telerehabilitation: Results from a Randomized Controlled Trial. PLoS ONE 2017, 12, e0177177, doi:10.1371/journal.pone.0177177.

33. Messinis, L.; Nasios, G.; Kosmidis, M.H.; Zampakis, P.; Malefaki, S.; Ntoskou, K.; Nousia, A.; Bakirtzis, C.; Grigoriadis, N.; Gourzis, P.; et al. Efficacy of a Computer-Assisted Cognitive Rehabilitation Intervention in Relapsing-Remitting Multiple Sclerosis Patients: A Multicenter Randomized Controlled Trial. Behavioural Neurology 2017, 2017, 1-17, doi:10.1155/2017/5919841.

34. Conroy, S.S.; Zhan, M.; Culpepper, W.J.; Royal, W.; Wallin, M.T. Self-Directed Exercise in Multiple Sclerosis: Evaluation of a Home Automated Tele-Management System. J Telemed Telecare 2018, 24, 410-419, doi:10.1177/1357633X17702757.

35. Stuifbergen, A.K.; Becker, H.; Perez, F.; Morrison, J.; Brown, A.; Kullberg, V.; Zhang, W. Computer-Assisted Cognitive Rehabilitation in Persons with Multiple Sclerosis: Results of a Multi-Site Randomized Controlled Trial with Six Month Follow-Up. Disabil Health J 2018, 11, 427-434, doi:10.1016/j.dhjo.2018.02.001.

36. Fjeldstad-Pardo, C.; Thiessen, A.; Pardo, G. Telerehabilitation in Multiple Sclerosis: Results of a Randomized Feasibility and Efficacy Pilot Study. Int J Telerehabil 2018, 10, 55-64, doi:10.5195/ijt.2018.6256.

37. Pöttgen, J.; Moss-Morris, R.; Wendebourg, J.-M.; Feddersen, L.; Lau, S.; Köpke, S.; Meyer, B.; Friede, T.; Penner, I.K.; Heesen, C.; et al. Randomised Controlled Trial of a Self-Guided Online Fatigue Intervention in Multiple Sclerosis. J Neurol Neurosurg Psychiatry 2018, 89, 970-976, doi:10.1136/jnnp-2017-317463. 
38. Cavalera, C.; Rovaris, M.; Mendozzi, L.; Pugnetti, L.; Garegnani, M.; Castelnuovo, G.; Molinari, E.; Pagnini, F. Online Meditation Training for People with Multiple Sclerosis: A Randomized Controlled Trial. Mult Scler 2019, 25, 610-617, doi:10.1177/1352458518761187.

39. Chiaravalloti, N.D.; Goverover, Y.; Costa, S.L.; DeLuca, J. A Pilot Study Examining Speed of Processing Training (SPT) to Improve Processing Speed in Persons With Multiple Sclerosis. Front. Neurol. 2018, 9, 685, doi:10.3389/fneur.2018.00685.

40. Plow, M.; Finlayson, M.; Liu, J.; Motl, R.W.; Bethoux, F.; Sattar, A. Randomized Controlled Trial of a TelephoneDelivered Physical Activity and Fatigue Self-Management Interventions in Adults With Multiple Sclerosis. Arch Phys Med Rehabil 2019, 100, 2006-2014, doi:10.1016/j.apmr.2019.04.022.

41. Fuchs, T.A.; Ziccardi, S.; Dwyer, M.G.; Charvet, L.E.; Bartnik, A.; Campbell, R.; Escobar, J.; Hojnacki, D.; Kolb, C.; Oship, D.; et al. Response Heterogeneity to Home-Based Restorative Cognitive Rehabilitation in Multiple Sclerosis: An Exploratory Study. Multiple Sclerosis and Related Disorders 2019, 34, 103-111, doi:10.1016/j.msard.2019.06.026.

42. Vilou, I.; Bakirtzis, C.; Artemiadis, A.; Ioannidis, P.; Papadimitriou, M.; Konstantinopoulou, E.; Aretouli, E.; Messinis, L.; Nasios, G.; Dardiotis, E.; et al. Computerized Cognitive Rehabilitation for Treatment of Cognitive Impairment in Multiple Sclerosis: An Explorative Study. J Integr Neurosci 2020, 19, 341-347, doi:10.31083/j.jin.2020.02.35.

43. Jeong, I.C.; Liu, J.; Finkelstein, J. Association Between System Usage Pattern and Impact of Web-Based Telerehabilitation in Patients with Multiple Sclerosis. Stud Health Technol Inform 2020, 272, 346-349, doi:10.3233/SHTI200566.

44. Kratz, A.L.; Atalla, M.; Whibley, D.; Myles, A.; Thurston, T.; Fritz, N.E. Calling Out MS Fatigue: Feasibility and Preliminary Effects of a Pilot Randomized Telephone-Delivered Exercise Intervention for Multiple Sclerosis Fatigue. J Neurol Phys Ther 2020, 44, 23-31, doi:10.1097/NPT.0000000000000296.

45. Flachenecker, P.; Bures, A.K.; Gawlik, A.; Weiland, A.-C.; Kuld, S.; Gusowski, K.; Streber, R.; Pfeifer, K.; Tallner, A. Efficacy of an Internet-Based Program to Promote Physical Activity and Exercise after Inpatient Rehabilitation in Persons with Multiple Sclerosis: A Randomized, Single-Blind, Controlled Study. Int J Environ Res Public Health 2020, 17, E4544, doi:10.3390/ijerph17124544.

46. Manns, P.J.; Mehrabani, G.; Norton, S.; Aminian, S.; Motl, R.W. The SitLess With MS Program: Intervention Feasibility and Change in Sedentary Behavior. Arch Rehabil Res Clin Transl 2020, 2, 100083, doi:10.1016/j.arrct.2020.100083.

47. Donkers, S.J.; Nickel, D.; Paul, L.; Wiegers, S.R.; Knox, K.B. Adherence to Physiotherapy-Guided Web-Based Exercise for Persons with Moderate-to-Severe Multiple Sclerosis: A Randomized Controlled Pilot Study. Int J MS Care 2020, 22, 208-214, doi:10.7224/1537-2073.2019-048.

48. Messinis, L.; Kosmidis, M.H.; Nasios, G.; Konitsiotis, S.; Ntoskou, A.; Bakirtzis, C.; Grigoriadis, N.; Patrikelis, P.; Panagiotopoulos, E.; Gourzis, P.; et al. Do Secondary Progressive Multiple Sclerosis Patients Benefit from Computer- Based Cognitive Neurorehabilitation? A Randomized Sham Controlled Trial. Mult Scler Relat Disord 2020, 39, 101932, doi:10.1016/j.msard.2020.101932.

49. Minen, M.T.; Schaubhut, K.B.; Morio, K. Smartphone Based Behavioral Therapy for Pain in Multiple Sclerosis (MS) Patients: A Feasibility Acceptability Randomized Controlled Study for the Treatment of Comorbid Migraine and Ms Pain. Multiple Sclerosis and Related Disorders 2020, 46, 102489, doi:10.1016/j.msard.2020.102489.

50. Van Geel, F.; Geurts, E.; Abasıyanık, Z.; Coninx, K.; Feys, P. Feasibility Study of a 10-Week Community-Based Program Using the WalkWithMe Application on Physical Activity, Walking, Fatigue and Cognition in Persons with Multiple Sclerosis. Multiple Sclerosis and Related Disorders 2020, 42, 102067, doi:10.1016/j.msard.2020.102067.

51. Bove, R.; Rowles, W.; Zhao, C.; Anderson, A.; Friedman, S.; Langdon, D.; Alexander, A.; Sacco, S.; Henry, R.; Gazzaley, A.; et al. A Novel In-Home Digital Treatment to Improve Processing Speed in People with Multiple Sclerosis: A Pilot Study. Mult Scler 2021, 27, 778-789, doi:10.1177/1352458520930371.

52. Tarakci, E.; Tarakci, D.; Hajebrahimi, F.; Budak, M. Supervised Exercises versus Telerehabilitation. Benefits for Persons with Multiple Sclerosis. Acta Neurol Scand 2021, doi:10.1111/ane.13448.

53. Williams, K.L.; Low Choy, N.L.; Brauer, S.G. Center-Based Group and Home-Based Individual Exercise Programs Have Similar Impacts on Gait and Balance in People With Multiple Sclerosis: A Randomized Trial. PM R 2021, 13, 9-18, doi:10.1002/pmrj.12377. 
54. Miller, D.M.; Moore, S.M.; Fox, R.J.; Atreja, A.; Fu, A.Z.; Lee, J.-C.; Saupe, W.; Stadtler, M.; Chakraborty, S.; Harris, C.M.; et al. Web-Based Self-Management for Patients with Multiple Sclerosis: A Practical, Randomized Trial. Telemedicine and e-Health 2011, 17, 5-13, doi:10.1089/tmj.2010.0133.

55. Greiner, P.; Sawka, A.; Imison, E. Patient and Physician Perspectives on MSdialog, an Electronic PRO Diary in Multiple Sclerosis. Patient 2015, 8, 541-550, doi:10.1007/s40271-015-0140-1.

56. D’hooghe, M.; Van Gassen, G.; Kos, D.; Bouquiaux, O.; Cambron, M.; Decoo, D.; Lysandropoulos, A.; Van Wijmeersch, B.; Willekens, B.; Penner, I.-K.; et al. Improving Fatigue in Multiple Sclerosis by SmartphoneSupported Energy Management: The MS TeleCoach Feasibility Study. Multiple Sclerosis and Related Disorders 2018, 22, 90-96, doi:10.1016/j.msard.2018.03.020.

57. Midaglia, L.; Mulero, P.; Montalban, X.; Graves, J.; Hauser, S.L.; Julian, L.; Baker, M.; Schadrack, J.; Gossens, C.; Scotland, A.; et al. Adherence and Satisfaction of Smartphone- and Smartwatch-Based Remote Active Testing and Passive Monitoring in People With Multiple Sclerosis: Nonrandomized Interventional Feasibility Study. J Med Internet Res 2019, 21, e14863, doi:10.2196/14863.

58. Newland, P.; Oliver, B.; Newland, J.M.; Thomas, F.P. Testing Feasibility of a Mobile Application to Monitor Fatigue in People With Multiple Sclerosis. Journal of Neuroscience Nursing 2019, 51, 331-334, doi:10.1097/JNN.0000000000000479.

59. Pratap, A.; Grant, D.; Vegesna, A.; Tummalacherla, M.; Cohan, S.; Deshpande, C.; Mangravite, L.; Omberg, L. Evaluating the Utility of Smartphone-Based Sensor Assessments in Persons With Multiple Sclerosis in the RealWorld Using an App (ElevateMS): Observational, Prospective Pilot Digital Health Study. JMIR Mhealth Uhealth 2020, 8, e22108, doi:10.2196/22108.

60. Baddeley, A. Working Memory; Clarendon Press/Oxford University Press, 1986;

61. Tacchino, A.; Pedullà, L.; Bonzano, L.; Vassallo, C.; Battaglia, M.A.; Mancardi, G.; Bove, M.; Brichetto, G. A New App for At-Home Cognitive Training: Description and Pilot Testing on Patients with Multiple Sclerosis. JMIR Mhealth Uhealth 2015, 3, e85, doi:10.2196/mhealth.4269.

62. Sohlberg, M.M.; Mateer, C.A. Effectiveness of an Attention-Training Program. Journal of Clinical and Experimental Neuropsychology 1987, 9, 117-130, doi:10.1080/01688638708405352.

63. Finkelstein, J.; Wood, J.; Shan, Y. Implementing Physical Telerehabilitation System for Patients with Multiple Sclerosis. In Proceedings of the 2011 4th International Conference on Biomedical Engineering and Informatics (BMEI); IEEE: Shanghai, China, October 2011; pp. 1883-1886.

64. Exell, S.; Program Lead Rebif, Global Clinical Development Center, EMD Serono, Inc., Rockland, Massachusetts, US; Thristan, M.; Manager, Business Analysis, EMD Serono, Inc., Rockland, Massachusetts, US; Dangond, F.; Head, US Medical Affairs, Neurodegenerative Diseases, EMD Serono, Inc., Rockland, Massachusetts, US; Marhardt, K.; Medical Affairs Director, Headquarter Medical Affairs Neurodegenerative Diseases, Merck Gesellschaft mbH, Vienna, Austria; Krohe, M.S.C.; Scientist, eResearch Technology, Inc. (ERT), Pittsburgh, Pennsylvania; et al. A Novel Electronic Application of Patient-Reported Outcomes in Multiple Sclerosis - Meeting the Necessary Challenge of Assessing Quality of Life and Outcomes in Daily Clinical Practice. European Neurological Review 2014, 9, 49, doi:10.17925/ENR.2014.09.01.49.

65. Williams, A.; Fossey, E.; Farhall, J.; Foley, F.; Thomas, N. Impact of Jointly Using an E-Mental Health Resource (Self-Management And Recovery Technology) on Interactions Between Service Users Experiencing Severe Mental Illness and Community Mental Health Workers: Grounded Theory Study. JMIR Ment Health 2021, 8, e25998, doi:10.2196/25998.

66. Lampit, A.; Heine, J.; Finke, C.; Barnett, M.H.; Valenzuela, M.; Wolf, A.; Leung, I.H.K.; Hill, N.T.M. Computerized Cognitive Training in Multiple Sclerosis: A Systematic Review and Meta-Analysis. Neurorehabil Neural Repair 2019, 33, 695-706, doi:10.1177/1545968319860490.

67. Yang, T.-T.; Wang, L.; Deng, X.-Y.; Yu, G. Pharmacological Treatments for Fatigue in Patients with Multiple Sclerosis: A Systematic Review and Meta-Analysis. J Neurol Sci 2017, 380, 256-261, doi:10.1016/j.jns.2017.07.042.

68. Heine, M.; van de Port, I.; Rietberg, M.B.; van Wegen, E.E.H.; Kwakkel, G. Exercise Therapy for Fatigue in Multiple Sclerosis. Cochrane Database Syst Rev 2015, CD009956, doi:10.1002/14651858.CD009956.pub2.

69. Tramontano, M.; Morone, G.; De Angelis, S.; Casagrande Conti, L.; Galeoto, G.; Grasso, M.G. Sensor-Based Technology for Upper Limb Rehabilitation in Patients with Multiple Sclerosis: A Randomized Controlled Trial. Restor Neurol Neurosci 2020, 38, 333-341, doi:10.3233/RNN-201033. 
70. Wendebourg, M.J.; Heesen, C.; Finlayson, M.; Meyer, B.; Pöttgen, J.; Köpke, S. Patient Education for People with Multiple Sclerosis-Associated Fatigue: A Systematic Review. PLoS One 2017, 12, e0173025, doi:10.1371/journal.pone.0173025.

71. Members of the MS in the 21st Century Steering Group:; Rieckmann, P.; Centonze, D.; Elovaara, I.; Giovannoni, G.; Havrdová, E.; Kesselring, J.; Kobelt, G.; Langdon, D.; Morrow, S.A.; et al. Unmet Needs, Burden of Treatment, and Patient Engagement in Multiple Sclerosis: A Combined Perspective from the MS in the 21st Century Steering Group. Mult Scler Relat Disord 2018, 19, 153-160, doi:10.1016/j.msard.2017.11.013.

72. Brydges, C.R. Effect Size Guidelines, Sample Size Calculations, and Statistical Power in Gerontology. Innovation in Aging 2019, 3, igz036, doi:10.1093/geroni/igz036.

73. Bonnechère, B.; Langley, C.; Sahakian, B.J. The Use of Commercial Computerised Cognitive Games in Older Adults: A Meta-Analysis. Scientific Reports 2020, 10, 15276, doi:10.1038/s41598-020-72281-3.

74. U.S. Food \& Drug Administration FDA Permits Marketing of First Game-Based Digital Therapeutic to Improve Attention Function in Children with ADHD Available online: https://www.fda.gov/news-events/pressannouncements/fda-permits-marketing-first-game-based-digital-therapeutic-improve-attention-functionchildren-adhd (accessed on 28 June 2021).

75. Marra, C.; Gordon, W.J.; Stern, A.D. Use of Connected Digital Products in Clinical Research Following the COVID19 Pandemic: A Comprehensive Analysis of Clinical Trials. BMJ Open 2021, 11, e047341, doi:10.1136/bmjopen2020-047341.

76. Carl, J.R.; Jones, D.J.; Lindhiem, O.J.; Doss, B.D.; Weingardt, K.R.; Timmons, A.C.; Comer, J.S. Regulating Digital Therapeutics for Mental Health: Opportunities, Challenges, and the Essential Role of Psychologists. Br J Clin Psychol 2021, doi:10.1111/bjc.12286.

77. Scott Kruse, C.; Karem, P.; Shifflett, K.; Vegi, L.; Ravi, K.; Brooks, M. Evaluating Barriers to Adopting Telemedicine Worldwide: A Systematic Review. J Telemed Telecare 2018, 24, 4-12, doi:10.1177/1357633X16674087.

78. Rangachari, P.; Mushiana, S.S.; Herbert, K. A Narrative Review of Factors Historically Influencing Telehealth Use across Six Medical Specialties in the United States. Int J Environ Res Public Health 2021, 18, 4995, doi:10.3390/ijerph18094995.

79. Almathami, H.K.Y.; Win, K.T.; Vlahu-Gjorgievska, E. Barriers and Facilitators That Influence Telemedicine-Based, Real-Time, Online Consultation at Patients' Homes: Systematic Literature Review. J Med Internet Res 2020, 22, e16407, doi:10.2196/16407.

80. Engelsma, T.; Jaspers, M.W.M.; Peute, L.W. Considerate MHealth Design for Older Adults with Alzheimer's Disease and Related Dementias (ADRD): A Scoping Review on Usability Barriers and Design Suggestions. Int J Med Inform 2021, 152, 104494, doi:10.1016/j.ijmedinf.2021.104494.

81. Bevens, W.; Gray, K.; Neate, S.L.; Nag, N.; Weiland, T.J.; Jelinek, G.A.; Simpson-Yap, S. Characteristics of MHealth App Use in an International Sample of People with Multiple Sclerosis. Mult Scler Relat Disord 2021, 54, 103092, doi:10.1016/j.msard.2021.103092.

82. Spina, E.; Trojsi, F.; Tozza, S.; Iovino, A.; Iodice, R.; Passaniti, C.; Abbadessa, G.; Bonavita, S.; Leocani, L.; Tedeschi, G.; et al. How to Manage with Telemedicine People with Neuromuscular Diseases? Neurol Sci 2021, doi:10.1007/s10072-021-05396-8.

83. Bergier, H.; Duron, L.; Sordet, C.; Kawka, L.; Schlencker, A.; Chasset, F.; Arnaud, L. Digital Health, Big Data and Smart Technologies for the Care of Patients with Systemic Autoimmune Diseases: Where Do We Stand? Autoimmun Rev 2021, 20, 102864, doi:10.1016/j.autrev.2021.102864.

84. Bonnechère, B.; Omelina, L.; Kostkova, K.; Van Sint Jan, S.; Jansen, B. The End of Active Video Games and the Consequences for Rehabilitation. Physiother Res Int 2018, 23, e1752, doi:10.1002/pri.1752. 
Table S1: Search strategy for PubMed

\begin{tabular}{|c|c|c|}
\hline & MeSH term & Hits \\
\hline \#1 population & $\begin{array}{l}\text { (multiple sclerosis) OR (ms) OR (multiple sclerosis[MeSH } \\
\text { Terms]) }\end{array}$ & 510,099 \\
\hline \#2 mHealth tool & $\begin{array}{c}\text { (ehealth[MeSH Terms]) OR (ehealth) OR (mhealth) OR } \\
\text { (mobile apps) OR (smartphone applications) OR (apps) }\end{array}$ & 68,807 \\
\hline $\begin{array}{l}\text { \#3 disease } \\
\text { management }\end{array}$ & $\begin{array}{l}\text { (self-monitoring) OR (self- assessment) OR (functioning) } \\
\text { OR (intervention) OR (rehabilitation) }\end{array}$ & $19,493,401$ \\
\hline$\# 1$ AND \#2 and \#3 & $\begin{array}{c}\text { ((multiple sclerosis) OR (ms) OR (multiple sclerosis[MeSH } \\
\text { Terms])) AND ((ehealth[MeSH Terms]) OR (ehealth) OR } \\
\text { (mhealth) OR (mobile apps) OR (smartphone applications) } \\
\text { OR (apps)) AND ((self-monitoring) OR (self-assessment) } \\
\text { OR (functioning) OR (intervention) OR (rehabilitation)) }\end{array}$ & 1,063 \\
\hline
\end{tabular}




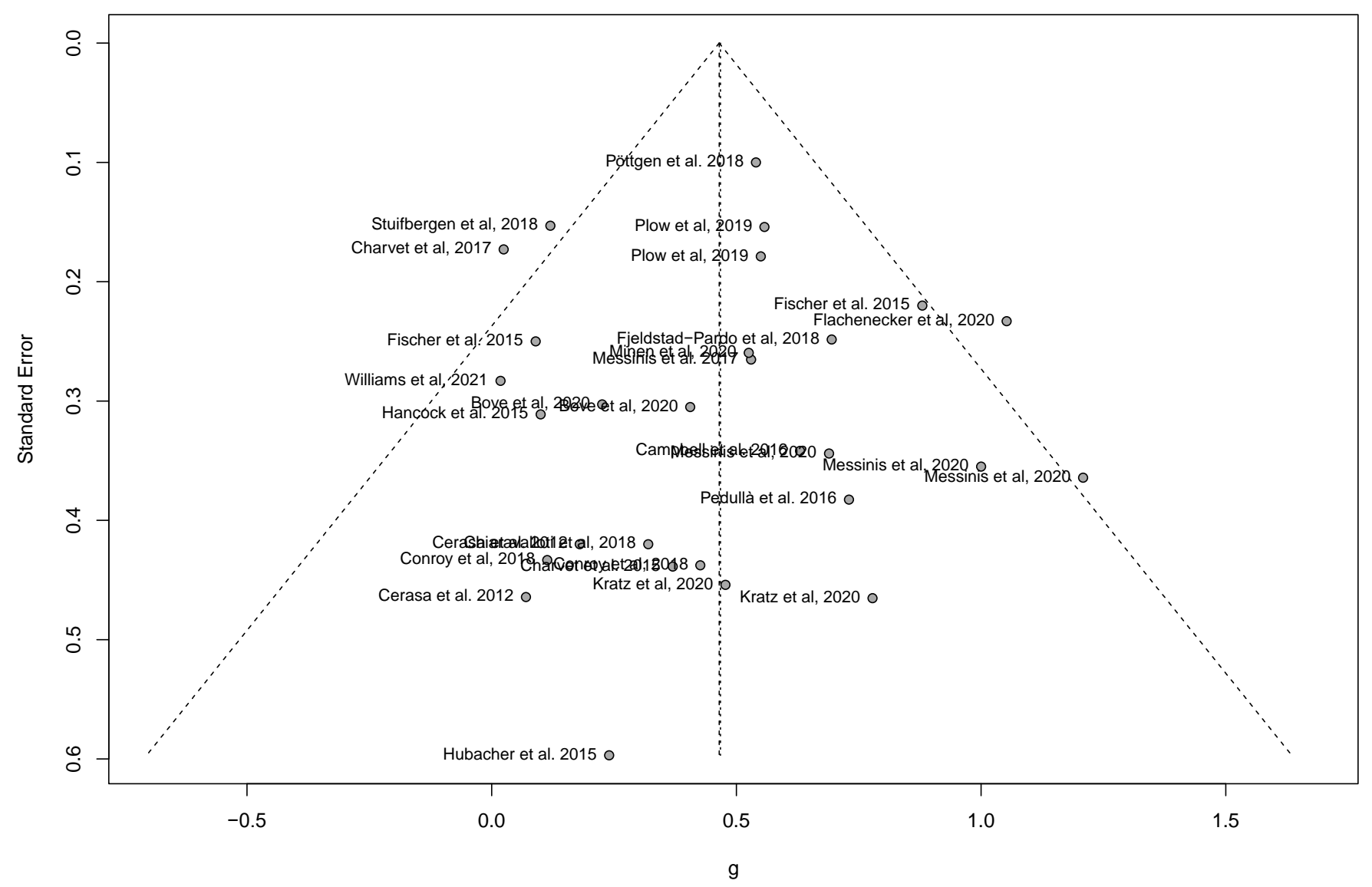

Figure S1. Funnel plot of the included studies in the meta-analysis 

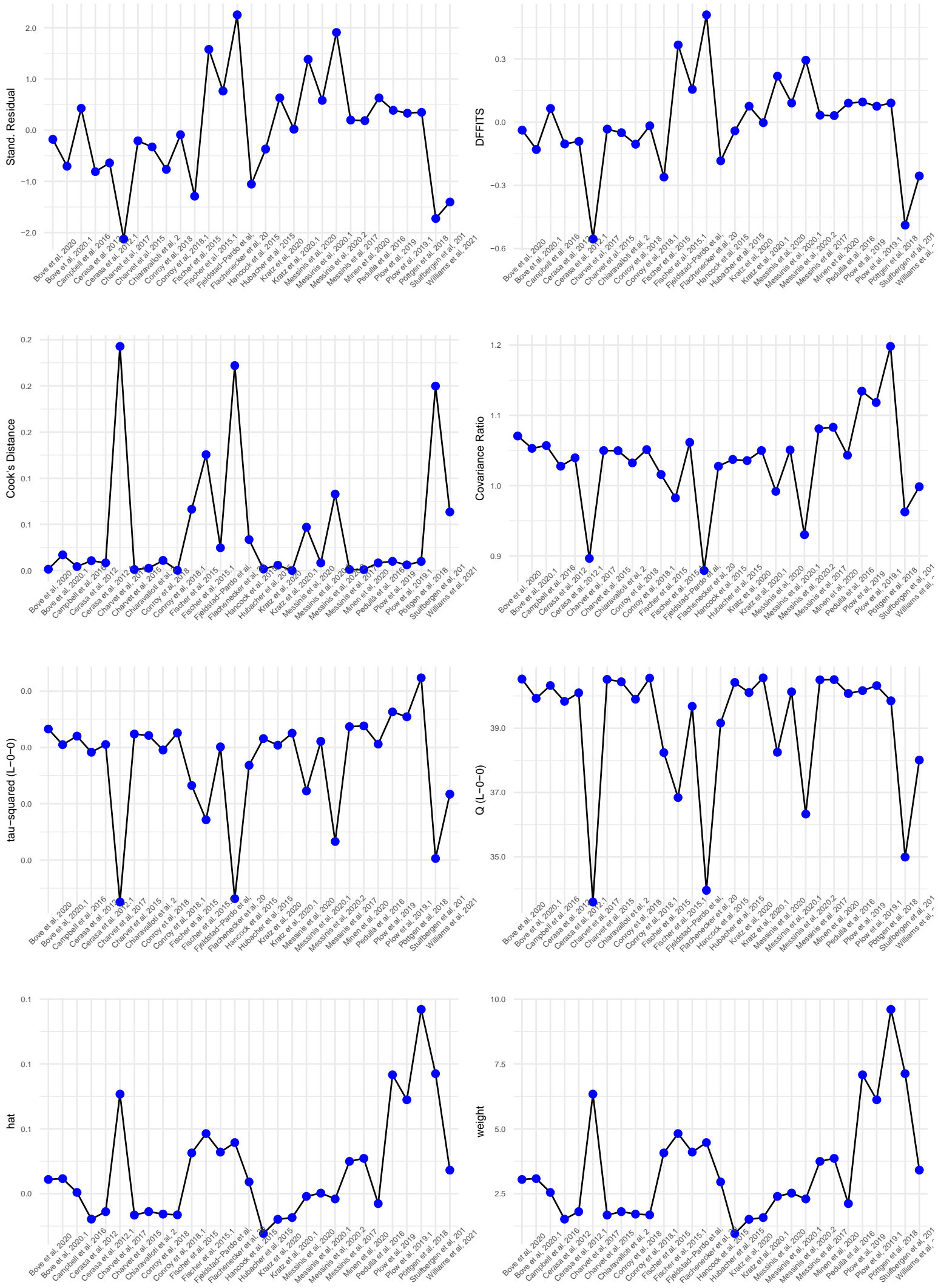

Figure S2. Sensitivity analysis of the included studies in the meta-analysis 